\title{
Enhancing Whole Phage Therapy and Their Derived Antimicrobial Enzymes through Complex Formulation
}

\author{
Callum J. Cooper *, Shazeeda Koonjan and Anders S. Nilsson * (D) \\ Department of Molecular Biosciences, The Wenner-Gren Institute, Stockholm University, \\ SE-10691 Stockholm, Sweden; shazeeda.koonjan@su.se \\ * Correspondence: callum.cooper@su.se (C.J.C.); anders.s.nilsson@su.se (A.S.N.)
}

Received: 20 March 2018; Accepted: 17 April 2018; Published: 19 April 2018

\begin{abstract}
The resurgence of research into phage biology and therapy is, in part, due to the increasing need for novel agents to treat multidrug-resistant infections. Despite a long clinical history in Eastern Europe and initial success within the food industry, commercialized phage products have yet to enter other sectors. This relative lack of success is, in part, due to the inherent biological limitations of whole phages. These include (but are not limited to) reaching target sites at sufficiently high concentrations to establish an infection which produces enough progeny phages to reduce the bacterial population in a clinically meaningful manner and the limited host range of some phages. Conversely, parallels can be drawn between antimicrobial enzymes derived from phages and conventional antibiotics. In the current article the biological limitations of whole phage-based therapeutics and their derived antimicrobial enzymes will be discussed. In addition, the ability of more complex formulations to address these issues, in the context of medical and non-medical applications, will also be included.
\end{abstract}

Keywords: bacteriophage; pharmacology; synergy; formulation; combination therapy; product development

\section{Introduction}

Renewed interest in the clinical and non-clinical application of phages and their derived antimicrobial enzymes has been stimulated by the need for new types of antibacterial agents to combat the ongoing problem of antibiotic resistance [1-4]. Although phages are still often compared to antibiotics, it is well established that they possess both advantages and disadvantages as therapeutic agents. In general, it is accepted that antibiotic treatments result in higher levels of collateral damage to pre-existing microflora due to their non-specific activities [5,6], while phage treatment minimizes this damage [7-9]. Therapy based upon the application of whole phages has traditionally been utilized in Eastern Europe to treat a variety of different infections ranging from diabetic foot ulcers to stomach complaints. This type of treatment takes advantage of the lytic replication cycle of wholly-virulent bacteriophages $[10,11]$.

A limited number of whole phage-based products have found success as food additives within Western markets and phage-derived enzymes show promising results, but they are yet to enter the mainstream as human or veterinary therapeutics (Table 1) [12-15]. There are many obstacles that need to be solved before phages can reach clinical settings and be widely applied in therapy. Many of these issues are associated with the nature and variation of phages, which influences everything from isolation and purification to potential formulation strategies. Each phage possesses unique properties that may or may not be desirable for targeted therapy, e.g., narrow host ranges, pharmacological criteria (burst sizes and latent period), and the ability to maintain bacterial killing in adverse conditions. 
There are also a number of factors regarding the bacterial host that must be considered, such as the number of targeted bacterial cells, their metabolic state, and the presence of phage defense mechanisms [16-19]. The vast complexity when these, and other factors, are combined makes it difficult to construct a universal phage formulation for a particular condition that can provide optimal phage efficacy while minimizing deleterious effects. These effects range from competition between phages within a cocktail to clearance by the immune system [20-23].

Increased levels of knowledge about phage genomes and their function within lytic replication has led to the identification of a number of phage derived proteins which have been shown to be powerful antibacterial agents in their own right [24-28]. These proteins are often produced during the latter stages of the phage replication cycle to aid in the release of newly-assembled phages from the bacterial host and have predominantly focused on endolysins $[29,30]$. However, it should be noted that other phage derived antimicrobial enzymes, including holins and spanins, have also been investigated [24,31].

Adjuncts and excipients are components of pharmaceutical preparations that can increase the activity of the main active ingredient when administered at the same time (e.g., the combination of caffeine and paracetamol) which play an important role in pharmaceutical formulations [32,33]. In normal pharmaceuticals, these additional components play important roles within the final formulations, ranging from increasing the shelf life of finished products to serving as binding agents, such as alginates, which can hold finished formulations together to produce pills [34,35]. The selection of appropriate adjunct compounds for each formulation is dependent on the nature of the therapy to be developed and is thought to reduce the failure rate in novel drug development [36]. As there have been reports of clinical successes of phage suspensions that presumably do not contain adjuncts, limited attention has been given to the development of more complex phage-based formulations that combine phages and additional pharmaceutical components. For therapies based upon whole phages or their derived antimicrobial enzymes, the formulation of biologically-active components with additional adjuncts may address a number of these factors.

The current review seeks to investigate the general issues associated with whole phage and phage derived antimicrobial enzymes (in particular endolysins as these are the most widely studied) and how they could be incorporated with compatible adjuncts for clinical and non-clinical applications. Areas in which complex formulations could potentially enhance the overall efficacy of therapies will also be highlighted. Although engineered phages and antimicrobial enzymes are also being investigated, they will not form part of the current review. 
Table 1. Summary of commercially available whole phage and phage-derived antimicrobial enzyme. FDA: Food and Drug Administration, USA, USDA FSIS: United States Department of Agriculture Food Safety and Inspection Service, GRAS: Generally Recognized as Safe, EPA: Environmental Protection Agency, USA.

\begin{tabular}{|c|c|c|c|c|c|}
\hline & Manufacturer & Product Name & Application & Approval Status & Reference \\
\hline \multirow{8}{*}{ Whole Phage } & \multirow{3}{*}{ Intralytix } & ListShieldTM & $\begin{array}{l}\text { Targets Listeria monocytogenes in food/food } \\
\text { processing }\end{array}$ & $\begin{array}{c}\text { Complies with FDA food additive rules } \\
\text { USDA FSIS listed safe } \\
\text { EPA-registered } \\
\text { Health Canada approved } \\
\text { National Food Services of Israel approved }\end{array}$ & [37] \\
\hline & & EcoShieldTM & Targets E. coli $0157: \mathrm{H7}$ in food/food processing & $\begin{array}{c}\text { FDA Cleared } \\
\text { Health Canada approved } \\
\text { National Food Service of Israel approved } \\
\text { USDA FSIS listed safe }\end{array}$ & [38] \\
\hline & & ShigaShieldTM & Targets Shigella species in food/food processing & GRAS for direct application & [40] \\
\hline & OmniLytics & AgriPhageTM & $\begin{array}{c}\text { Targets bacterial spot, bacterial speck and } \\
\text { bacterial canker on tomato and pepper plants }\end{array}$ & EPA registered & [41] \\
\hline & \multirow[b]{2}{*}{ Pherecydes Pharma } & PhagoBurn & Targets skin infections in burn wounds & Phase 2 clinical trials & {$[42,43]$} \\
\hline & & PneumoPhage & $\begin{array}{l}\text { Targets Pseudomonas aeruginosa in acute } \\
\text { respiratory tract infections }\end{array}$ & - & [44] \\
\hline & \multirow{2}{*}{$\begin{array}{l}\text { AmpliPhi Biosciences } \\
\text { Corporation }\end{array}$} & AB-SA01 & Targets S. aureus & $\begin{array}{l}\text { Expanded Access } \\
\text { Phase } 1 \text { completed }\end{array}$ & [46] \\
\hline & & AB-PA01 & Targets Pseudomonas aeruginosa & Expanded Access & \\
\hline \multirow{3}{*}{ Endolysin } & Micreos Human Health & StaphefektTM & Endolysin that targets S. aureus and MRSA & Interventional Clinical Trial & {$[15,47,48]$} \\
\hline & \multirow{2}{*}{ ContraFect } & \multirow{2}{*}{ CF-301 } & \multirow{2}{*}{$\begin{array}{l}\text { Phage-derived lysin that targets S. aureus blood } \\
\text { stream infections }\end{array}$} & Completed Phase 1 clinical trials & \multirow{2}{*}{ [49] } \\
\hline & & & & Granted Fast Track Designation from FDA & \\
\hline
\end{tabular}




\section{Compound Selection and Pre-Formulation Testing}

In the development of pharmaceutical adjuncts and novel biocides, clearly established protocols and legislation exist for determining safety and efficacy, both as individual compounds and also when part of formulations, with requirements that vary by application (Table 2) [50]. For phage-derived antimicrobial enzymes, the activity and host range could be easily assessed using pre-existing antibiotic susceptibility testing methods $[51,52]$. However, there are currently multiple methods that can be used when determining the activity of single whole phages [53-56]. Although these methods are based upon the ability of the phage to produce plaques in a bacterial lawn, they have been shown to produce varying results [56], and it is widely accepted that only purely-lytic phages should be utilized and that their inherent characteristics (e.g., burst size, host range) should be considered for therapy [57,58], As such, it is essential that rapid, easy to use, quantitative assays are developed which can differentiate between multiple phages.

Once the initial characterization of the phage or antimicrobial enzyme had been performed, and prior to assessing the overall effects of a finished formulation, it would be necessary to know the impact of any potential adverse or additive effects that adjunct compounds provide to the phages or the derived antimicrobial enzymes themselves, as well as the impact upon the bacterial host $[59,60]$. Perhaps the most obvious concern would be a decrease in the stability or activity of the phages or their derived antimicrobial enzymes. In the case of whole phages, this is likely to arise as the result of broad-spectrum antimicrobial activity which may potentially inactivate the phage along with the bacterial host [59-61], while in the case of phage-derived antimicrobial enzymes, this could be achieved through the modification of protein domains as the result of residue oxidation [62]. Therefore, in order to counteract these potentially harmful effects, it would be necessary to optimize the concentrations of these compounds in order to minimize the damage that they could cause to the active component without completely losing any beneficial effects they provide, using standardized test regimes, such as fractional inhibitory concentration (FIC) or checkerboard testing [63,64].

It is also necessary to consider the solubility of both the adjuncts and the phage/enzymes during the initial selection process. Unlike antibiotics, whose concentrations, in many cases, can be increased to levels that are toxic to humans, it is possible that phages will possess an upper threshold of what can be held in suspension, approximately $10^{14} \mathrm{PFU} / \mathrm{mL}$ for a small phage, such as $\mathrm{T} 7$, due to the differences between their sizes [65]. Such an upper threshold should limit the maximum concentration of each individual component within a cocktail. The limitation on the upper concentration threshold could result in an overall decrease in the level of activity. However, commercially available whole phage products can be routinely produced at titers $\geq 10^{10} \mathrm{PFU} / \mathrm{mL}$ and are used at concentrations of approximately $10^{9} \mathrm{PFU} / \mathrm{mL}$ [66]. If necessary, solubility could theoretically be increased through the addition of solubilizing agents, such as polysorbate 80, dimethyl sulfoxide (DMSO), or glycerin [67], it should be noted that some solubilizing agents, such as DMSO, can be antimicrobial at higher concentrations.

Table 2. Requirements for pharmaceutical preparations by application type. $\mathrm{G}^{-}$: Gram-negative [13,68-71].

\begin{tabular}{|c|c|c|c|c|c|c|}
\hline \multicolumn{2}{|c|}{$\begin{array}{c}\text { Route of } \\
\text { Administration }\end{array}$} & $\begin{array}{c}\text { Total Aerobic } \\
\text { Microbial Count } \\
\text { (CFU/g or CFU/mL) }\end{array}$ & $\begin{array}{c}\text { Total Combined } \\
\text { Yeast/Mold Count } \\
\text { (CFU/g or CFU/mL) }\end{array}$ & $\begin{array}{l}\text { Absence of Specific } \\
\text { Microorganisms }\end{array}$ & $\begin{array}{c}\text { cGMP } \\
\text { Requirement }\end{array}$ & $\begin{array}{c}\text { Defined } \\
\text { Endotoxin } \\
\text { Limits }\end{array}$ \\
\hline \multirow{3}{*}{ Oral } & Non-aqueous & $10^{3}$ & $10^{2}$ & \multirow{2}{*}{ E. coli } & \multirow{3}{*}{ Yes } & \multirow{3}{*}{ No } \\
\hline & Aqueous & $10^{2}$ & $10^{1}$ & & & \\
\hline & Buccal/Gingival & $10^{2}$ & $10^{1}$ & S. aureus & & \\
\hline \multirow{3}{*}{ Skin } & Transdermal & \multirow{2}{*}{$10^{2}$} & \multirow{2}{*}{$10^{1}$} & \multirow{2}{*}{ S. aureus and $P$. aeruginosa } & \multirow{3}{*}{ Yes } & \multirow{2}{*}{ No } \\
\hline & Cutaneous & & & & & \\
\hline & Injectable & 0 & 0 & - & & Yes \\
\hline & Vaginal & $10^{2}$ & $10^{1}$ & $\begin{array}{l}\text { S. aureus and P. aeruginosa and } \\
\text { Candida albicans }\end{array}$ & Yes & No \\
\hline & Rectal & $10^{3}$ & $10^{2}$ & - & Yes & No \\
\hline & Inhalation & $10^{2}$ & $10^{1}$ & $\begin{array}{l}\text { S. aureus, } P \text {. aeruginosa and bile } \\
\text { tolerant } \mathrm{G}^{-} \text {bacteria }\end{array}$ & Yes & No \\
\hline
\end{tabular}




\section{Increasing Antibacterial Activity and Host Range}

Among the key double-edged advantages of therapies (based upon whole phages or their derived antimicrobial enzymes compared to conventional antibiotics) is that their specific activity minimizes the collateral damage to commensal microflora at the same time as limiting the host range of each therapy. When designing whole-phage-based therapies, multiple phages are combined into cocktails, with the selection of phages with optimal characteristics of key importance. However, it is often assumed that the best criteria for phage activity are dependent on in vitro properties and independent of the type of application $[57,58,68,72]$. This could lead to the exclusion of some phages which may better suit a particular application. For example, if one was to attempt to reduce the risk of contracting a particular disease in a cattle herd (prevention therapy), such as mastitis, then a phage cocktail which possesses a broad host range, greater environmental stability, and longer lasting lytic activity would prove more useful than a cocktail which targets a limited number of hosts and is susceptible to environmental conditions. Conversely, for active infections against a single characterized bacterium, faster-acting phages with large burst sizes would be more useful (intervention therapy). In the sections below, combinations of phages, their derived antimicrobial enzymes, and additional compounds will be discussed.

\subsection{Phage Cocktails}

Perhaps the most routinely used and well-studied form of formulation, phage cocktails are comprised of multiple phages on the basis of desirable in vitro characteristics (e.g., activity and/or host range) in order to enhance the host range and potentiate overall activity when compared to the individual components [73-76]. A summary of in vivo cocktail testing can be found in Table 3. Such combinations possess significantly more complex dynamics compared to individual phages have been reviewed in detail elsewhere and are generally shown to increase antibacterial activity compared to individual phages [76-78]. Although phage cocktails are well studied, there are a number of areas in which additional research could be focused on (e.g., increasing phage host range, phage pharmacology, host immune response, etc. [79]), which would provide additional information for the selection of phages in cocktails.

Some of the complexities of active treatment (interventionist) phage cocktail dynamics involve the ability of a single phages to outcompete the other phage components of the cocktail via competition for bacterial binding sites and the loss of phage activity from superinfection exclusion, to lower-risk outcomes which may include the inability to infect resistant bacteria compared to a single phage $[18,19,76,78]$. While competition for binding sites is perhaps the most obvious example of this, competition could also arise from differences in the replication dynamics of the phage in which one phage possesses a shorter latent period (the time between infection and bacterial lysis) compared to other phages in the cocktail. This competition could, thus, decrease the overall efficacy of the treatment through the faster propagation one of them gets. Indeed, within the published literature, the change in the titer of individual phage components is often not studied and, instead, relies upon the reporting of the total phage content [80-82]. Competition between phages for bacterial binding sites could also potentially have a deleterious effect on phage activities in cocktails where phages are applied simultaneously (immediate release), in the absence of any other compounds or formulation and, as such, it would be advantageous to select phages which target different bacterial receptors. Although there are a number of well-characterized examples of surface receptors for phage binding [83-85], they are often overlooked when selecting phages. 
Table 3. Summary of non-safety in vivo phage cocktail studies. i.c.: intracavity wash; i.v.: intravenous.

\begin{tabular}{|c|c|c|c|c|}
\hline Condition Targeted & Bacterial Species & Cocktail Composition & Results & References \\
\hline Human Chronic otitis & P. aeruginosa & $\begin{array}{l}\text { Biophage PA (six phages; BC-BP-01 } \\
\text { to BC-BP-06) } 10^{5} \text { PFU per phage }\end{array}$ & $\begin{array}{l}\text { - Clinical indicators improved in phage treated patients } \\
\text { compared to placebo } \\
\text { P. aeruginosa counts significantly lower in phage } \\
\text { treated group compared to placebo }\end{array}$ & [86] \\
\hline Human necrotic pancreatitis & Acinetobacter baumnnii & $\begin{array}{l}\text { Three phage cocktails used; } \phi \mathrm{PC} \\
\text { (i.c.), } \phi \mathrm{IV}\left(5 \times 10^{9} \mathrm{PFU} \text { i.v. }\right) \text { and } \\
\quad \phi \mathrm{IVB}\left(5 \times 10^{9} \mathrm{PFU} \text { i.v. }\right)\end{array}$ & $\begin{array}{l}\text { - } \quad \text { Patient survived and fully recovered } \\
\text { - } \quad \text { Pesistance to cocktails } \phi \mathrm{PC} \text { and } \phi \mathrm{IV} \text { after } 8 \text { days } \\
\text { after } 120 \mathrm{~min}\end{array}$ & [87] \\
\hline Murine Bacteremia & Klebsiella pneumoniae & GH-K1, GH-K2, GH-K3 & $\begin{array}{l}\text { - Cocktail reduced bacterial titre approx. } 3-4 \log _{10} \\
\text { compared to monophage } \\
\text { - Cocktail counts decreased } \leq 2 \log _{10} \text { in } 90-120 \mathrm{~min}\end{array}$ & [88] \\
\hline $\begin{array}{l}\text { Necrotic Enteritis of boiler } \\
\text { chickens }\end{array}$ & Clostridium perfringens & $\begin{array}{l}\text { C. perfringens phages (CPAS-7, } \\
\text { CPAS-12, CPAS-15, CPAS-16and } \\
\text { CPLV-42) in equal amounts }\end{array}$ & $\begin{array}{l}\text { - Mortality }<1 \% \text { when administered with water or feed. } \\
\text { Compared to } 64 \% \text { in controls }\end{array}$ & [89] \\
\hline Mouse model of mastitis & S. aureus & $\begin{array}{l}\text { Twelve phage cocktail (composition } \\
\text { unknown except for two phages; } \\
\text { BP39 and mutant of ATCC 23361) }\end{array}$ & $\begin{array}{l}\text { - Bacterial counts approximately } 4-5 \log _{10} \text { in mammary } \\
\text { tissue for cocktail treated group compared } \leq 2 \log _{10} \text { for } \\
\text { cefalonium treated control. }\end{array}$ & [90] \\
\hline
\end{tabular}




\subsection{Combination with Antibiotics}

With the rise of multidrug antibiotic resistance among once-susceptible bacteria, such as Klebsiella pneumoniae, multiple antibiotics are often combined to produce an effective therapy [91,92]. With combination therapy, the aim is to produce a synergistic or additive effect which eradicates the infection. Although there are a number of studies which suggest that these antibiotic combinations could select for mutations, allowing for broad-spectrum resistances which can be passed on to susceptible bacteria, the data remains contradictory [91,93-96]. As such, the use of phages and antibiotics in combination could prove to be beneficial, as there is data to suggest that overall activity of formulations is increased (Table 4) and that the formulation selects against drug-resistant phenotypes [97-101]. This synergistic potential has also been demonstrated for a number of endolysin/antibiotic combinations [102,103]. However, the combination of phages and antibiotics could potentially reduce the overall activity of the phage component in an active treatment, by targeting phage-infected and non-infected cells alike, and potentially interfere with phage replication.

In one such study by Oechslin and colleagues, a 12-phage cocktail (PP1131 at $10^{8} \mathrm{PFU} / \mathrm{mL}$ ) which targeted $P$. aeruginosa was able to increase the in vitro bacterial kill by over $4 \log _{10}$ over a $24-h$ period when combined with 2.5 times the minimum inhibitory concentration (MIC) of ciprofloxacin (a known inducer of prophages) or meropenem when compared to phage or antibiotic alone. In vivo studies by the same group showed that the cocktail possessed a half-life of approximately $2.3 \mathrm{~h}$ in the plasma while the half-life was reported as approximately $9 \mathrm{~h}$ in other organs and that in animals with endocarditis, negative cultures $\left(\leq 2 \log _{10} \mathrm{CFU} / \mathrm{g}\right)$ were observed in seven of the 11 animals provided combination therapy compared to monotherapy groups ( $\geq 6 \log _{10} \mathrm{CFU} / \mathrm{g}$ ) [80].

The combination of antibiotics and bacteriophage-derived endolysins has also been shown to increase antibacterial activity components in Gram-positive bacteria. A study by Becker et al. demonstrated that there was a strong synergy between the LysK and lysostaphin using a turbidity reduction assay providing a calculated $\Sigma$ FIC of $0.45 \pm 0.07$ [102]. A synergistic effect was also shown by Garcia and colleagues who demonstrated that the combination of the Staphylococcal endolysin LysH5 with Nisin was able to induce synergy and increase the antibacterial activity eight-fold against a single strain of Staphylococcus aureus in a checkerboard MIC assay and pasteurized milk [104]. While this approach shows promise for Gram-positive pathogens, there is limited knowledge on the combinations of endolysins and antibiotics against Gram-negative pathogens.

The global consumption of antibiotics has increased between 2000 and 2010 and there are a number of different strategies for combatting this. The introduction of antibiotic stewardship programs is one such strategy to reduce consumption in human and veterinary medicine [2,105-107]. Although such stewardship programs and combinations are shown to possess advantages (increased overall activity, etc.) combining phages with antibiotics is counterintuitive, if the overall aim of these programs is to reduce the consumption of antibiotics. Such a move would not necessarily significantly impact the amount of antibiotics used in combinatorial therapy and the need for broad-spectrum agents would also not decrease. As such, additional research into combinatorial therapy with other non-antibiotic agents should be undertaken.

\subsection{Combination with Natural Products with Antibacterial Activity}

Although much focus has been placed on the combination of phages with antibiotics (both bactericidal and bacteriostatic), there is little in the way of investigation into the effects of non-antibiotic antibacterial compounds in combination with phages (Table 5). As with the development of phage therapy, the use of bulk natural compounds or chemical extracts of these compounds continues to attract interest as alternative antimicrobial agents as both solo agents and also as antibiotic adjuncts $[108,109]$. The induction of a non-phage-based synergistic or additive response represents an alternative way to increase the overall level of phage therapeutics while potentially simplifying the dynamics of the therapy. However, while research into combination therapy with antibiotics is ongoing, the synergistic potential of phages with other non-antibiotic antibacterial adjunct compounds is a currently-understudied area $[97-99,110,111]$. 
Table 4. Examples of phage or derived antimicrobial enzymes and antibiotic combinations. Antibiotic abbreviations based on BSAC where available [112].

\begin{tabular}{|c|c|c|c|c|}
\hline & Bacterial Target & Combination Tested & Results & References \\
\hline \multirow{6}{*}{ Phage } & \multirow[b]{2}{*}{ P. aeruginosa } & $\begin{array}{l}\text { Phages } \sigma, \sigma-1 \text { or } 001 \mathrm{~A} / \text { subinhibitory } \mathrm{GEN}, \mathrm{CIP}, \\
\text { ceftriaxone or polymixin B }\end{array}$ & $\begin{array}{l}\text { - No additive effect in GEN and polymixin B combinations } \\
\text { individual componanents by } 300 \mathrm{~min}\end{array}$ & [98] \\
\hline & & Phage LU27/Streptomycin 120 or $240 \mu \mathrm{g} / \mathrm{mL}$ & $\begin{array}{l}\text { - Phage only control showed approx. } 1 \log 10 \text { reduction at } 70 \mathrm{~h} \\
\text { - Bacterial reduction } 2-3 \log _{10} \text { reduction in } 100 \mu \mathrm{m} / \mathrm{mL} \text { streptomycin/phage } \\
\text { combination compared to streptomycin only at } 70 \mathrm{~h} \\
\text { - Delay in antibiotic addition altered pattern of kill }\end{array}$ & [113] \\
\hline & Burkholderia cepacia Complex & $\begin{array}{c}\text { Phage KS12/1.25 } \mu \mathrm{g} / \mathrm{mL} \text { CIP, } 5 \mu \mathrm{\mu g} / \mathrm{mL} \text { MEM, } \\
5.5 \mu \mathrm{g} / \mathrm{mL} \text { TET }\end{array}$ & $\begin{array}{l}\text { - Phage/CIP and MEM combinations showed } \geq 3 \log _{10} \text { reduction at } 325 \mathrm{~min} \\
\text { compared to controls }\end{array}$ & [99] \\
\hline & E. coli & Phage $\phi \mathrm{MFP} / 50$ or $20 \mathrm{ng} / \mathrm{mL}$ CTX & $\begin{array}{l}\text { - Phage titer increased by approx. } 1 \log _{10} \text { by } 120 \mathrm{~min} \text { post administration } \\
\text { - Plaque sizes increased compared to control }\end{array}$ & [114] \\
\hline & К. рпиетопіае & Phage B5055/CIP & $\begin{array}{l}\text { - Reduction of bacterial biofilm content of approx. } 5 \log _{10} 180 \mathrm{~min} \text { after } \\
\text { phage addition } \\
\text { No significant difference in reduction between combination and phage } \\
\text { only treated biofilms } \\
\text { - Frequency of resistant variants decreased in combined testing compared to } \\
\text { individual components }\end{array}$ & [115] \\
\hline & S. aureus & Phage MR-10/5 mg/Kg MUP & $\begin{array}{l}\text { - Phage/MUP combination showed }>1 \log _{10} \text { reduction in bacterial content by } \\
\text { day } 3 \text { post treatment in BALB/c mice compared to controls } \\
\text { - Clearance in Phage/MUP combination by day } 5 \\
\text { - Individual components showed clearance by day } 10\end{array}$ & [116] \\
\hline \multirow{4}{*}{$\begin{array}{l}\text { Derived } \\
\text { antimicrobial } \\
\text { enzymes }\end{array}$} & Streptococcus pneumoniae & Endolysin Cpl-1/GEN or PEN & - Synergy with PEN or GEN was dependent on level of PEN resistance & [117] \\
\hline & A. baumannii & $\begin{array}{l}\text { Endolyin LysABP- } 01 \text { (concentrations ranged from } \\
0.0156-2 \times \text { MIC)/CIP, IMP, COL, CHLO, GEN, ERY, or } \\
\text { TET (concentrations ranged from } 0.0625-2 \times \text { MIC) }\end{array}$ & $\begin{array}{l}\text { - Phage/COL showed elevated antibacterial activity (close to } 100 \% \text { ) in } \\
\text { comparison to other phage/antibiotic combination }\end{array}$ & [118] \\
\hline & Listeria monocytogenes & Endolysin PlyP100/nisin & $\begin{array}{l}\text { - Endolysin stable for up to } 28 \text { days under cold storage } \\
\text { - PlyP100/nisin combination maintained activity over } 4 \text { weeks }\end{array}$ & [119] \\
\hline & S. aureus & CF-301/ DAP, VAN & $\begin{array}{l}\text { - Synergy between CF-301 and DAP/VAN resulted in increased murine } \\
\text { survival compared to when just treated with antibiotics alone }(p<0.0001)\end{array}$ & [103] \\
\hline
\end{tabular}


Table 5. Examples of phages or derived antimicrobial enzymes in combination non-antibiotic compounds.

\begin{tabular}{|c|c|c|c|c|}
\hline & Bacterial Target & Combination & Results & References \\
\hline \multirow{3}{*}{ Phage } & K. pneumoniae & Phage KPO1K2 or NDP/ $\mathrm{CoSO}_{4}$ or $\mathrm{FeCl}_{3}$ & $\begin{array}{l}\text { - Reduction of } \leq 1 \log _{10} \text { in } \mathrm{NDP} / 10 \mu \mathrm{M} \mathrm{FeCl} l_{3} \text { combination in biofilms up to seven } \\
\text { days versus untreated control } \\
\text { - Reduction of } 1-2 \log _{10} \text { in } \mathrm{KPO} 1 \mathrm{~K} 2 / 10 \mu \mathrm{M} \mathrm{FeCl}_{3} \text { combination in biofilms up to } \\
\text { seven days versus untreated control } \\
\text { - Reduction of } \geq 5 \log _{10} \text { in } \mathrm{KPO} 1 \mathrm{~K} 2 / 10 \mu \mathrm{M} \mathrm{FeCl}_{3}+500 \mu \mathrm{M} \mathrm{CoSO}_{4} \text { combination in } \\
\text { three day old biofilms versus untreated control }\end{array}$ & [120] \\
\hline & E. coli O157:H7 & $\begin{array}{l}\text { Phage cocktail BEC } 8\left(10^{6} \mathrm{PFU} / \text { leaf }\right) / 0.5 \% \\
v / v \text { trans-cinnameldehyde }\end{array}$ & $\begin{array}{l}\text { - Total kill (4-6 } \log _{10} \text { reduction) within } 10 \mathrm{~min} \text { when combined at all conditions } \\
\text { - Individual treatment results varied based on bacterial inoculum and } \\
\text { incubation temperature }\end{array}$ & [121] \\
\hline & L. monocytogenes & $\begin{array}{l}\text { Listex P100/potassium lactate and } \\
\text { sodium diacetate }\end{array}$ & $\begin{array}{l}\text { - Prevented L. monocytogenes outgrowth for up to28 days compared to controls } \\
\text { - Smaller reduction in bacterial count seen at lower temperatures }\end{array}$ & [122] \\
\hline \multirow{4}{*}{$\begin{array}{l}\text { Derived } \\
\text { antimicrobial } \\
\text { enzymes }\end{array}$} & S. aureus & $\begin{array}{l}\text { Endolysin LysSA97 (376 nM)/carvacrol } \\
\qquad(3.33 \mathrm{mM})\end{array}$ & $\begin{array}{l}\text { - Individual components showed reduction in bacterial content of approx. } 1 \log _{10} \\
\text { - Combination reduced bacterial content }>4 \log _{10} \\
\text { - Combined activity varied depending on lipid content }\end{array}$ & [123] \\
\hline & L. monocytogenes & $\begin{array}{l}\text { Endolysin PlyP825/High hydrostatic } \\
\text { pressure (HHP) }\end{array}$ & $\begin{array}{l}\text { - Synergistic inactivation of L. monocytogenes in milk, cheese, and smoked fish } \\
\text { - Allows for lower pressure level to be used with the same antimicrobial efficacy } \\
\text { when treated in combination with phage } \\
\text { - Decrease bacteria positive food samples during storage }\end{array}$ & [124] \\
\hline & & $\begin{array}{l}\text { Endolysin PlyP40, Ply511 or } \\
\text { PlyP825/High pressure }\end{array}$ & $\begin{array}{l}\text { - } \quad \text { Individual treatment reduced bacterial number } \leq 1 \log _{10} \\
\quad \text { Combined treatment reduced bacterial number } \geq 5 \log _{10}\end{array}$ & [125] \\
\hline & Various & Endolysin Lys68/weak acids & $\begin{array}{l}\text { - Lys68/EDTA combination only lysed Pseudomonas } \\
\text { - } \quad \text { Lys68/citric or malic acid effected } 9 \text { or } 11 \text { species, respectively } \\
\text { - Bacterial reduction }<3 \log _{10} \text { for all conditions tested }\end{array}$ & [126] \\
\hline
\end{tabular}


As with phages, honey has a long history as an antimicrobial agent and has been shown to target multiple bacterial pathogens, inhibit biofilm formation, and may increase wound healing [127-131]. The broad antimicrobial properties of honey stem from the presence of hydrogen peroxide [132], a high sugar content, and the presence of methylglyoxal (MGO) and the antimicrobial peptide bee defensin-1 [133]. However, it should also be noted that the composition of antimicrobial agents between honeys differs dramatically even within localized areas [134,135]. A recent study by Oliveira and colleagues has also shown that phages in combination with one of two Portuguese honeys were able to increase the bactericidal effect against Escherichia coli biofilms over a $24 \mathrm{~h}$ period compared to the phage or alone. However, this increase in antibacterial activity was coupled with a reduction in phage titer of at least $1 \log _{10}$ within 60 min compared to the inoculum at the lowest concentration of honey tested [60]. This broad-spectrum antimicrobial activity is undoubtedly useful, but would present a potential hazard if trying to combine honey with endolysins as both MGO and hydrogen peroxide act against protein structures via cross-linkage or hydroxyl radical formulation, respectively [136].

The risk of broad spectrum antimicrobial activity when combined with bulk antimicrobial plant extracts is also seen in Pimchan et al [59]. This study compared the antibacterial effects of three different bulk plant extracts from plants with known antibacterial properties in combination with two different E. coli phages. As the plant extracts were diluted to reduce the potential adverse effects on the viability of the phages, a loss of phage titer of approximately $1 \log _{10}$ was only observed for one of the conditions tested. However, this also reduced the overall antibacterial activity compared to the phage alone [59].

Volatile essential oils, such as thymol and carvacrol, extracted from plant materials have also been previously shown to possess potent antimicrobial properties [137,138]. A study by Ghosh et al. evaluated the antibacterial properties of Staphylococcal Phage K and a number of essential oil compounds on the in vitro growth of $S$. aureus. While both essential oils tested individually were able to significantly reduce the growth of multiple strains of $S$. aureus at $37^{\circ} \mathrm{C}$, when combined, the effect was not greatly changed [139]. In contrast to this, Chang and colleagues demonstrated synergy between carvacrol and the LysSA97 endolysin in milk with individual components producing approximately a $1 \log _{10}$ reduction in bacterial content while the combination reduced bacterial content by approximately $4.5 \log _{10}$. This study also suggested that an increased lipid content decreased the synergistic activity [123].

While the combination of natural products and bacteriophages appears to exhibit some promise, extra attention should be paid to the characterization of active components within bulk compounds. Such an approach could potentially yield compounds with potent and specific antibacterial properties. In addition, determining the mechanism of action of such compounds would also be of use. In particular, the selection of compounds which do not interfere with protein structure would be advantageous for both whole phage and phage-derived antimicrobial enzymes.

\subsection{Combination with Non-Antibacterial Compounds}

Although the combination of additional antibacterial agents with phages or their derived antimicrobial enzymes could increase the overall activity of formulations and would be advantageous in intervention therapies, it only enhances a single aspect, the overall kill, and only targets vegetative bacterial species. For preventative measures the overall level of bacterial kill is less important and the ability of the phage to infect its bacterial host becomes more important. As such, the enhancement of the binding and adsorption efficacy of the phage or phage-derived antimicrobial enzyme (e.g., endolysins) could also increase the efficacy of preventative treatments.

The presence of divalent ions (particularly $\mathrm{Ca}^{2+}$ ions) is well known to play a role in enhancing the binding efficacy of phages and many phage buffers consequently are supplemented with $\mathrm{Ca}^{2+}$ ions (Table 5) [120,140-142]. A study by Bandara and colleagues showed that $\mathrm{Ca}^{2+}, \mathrm{Mg}^{2+}$ or $\mathrm{Mn}^{2+}$ ions were required to allow Bacillus Phages BCP1-1 and BCP8-2 to infect Bacillus cereus strains in a fermented soybean paste [143]. A study by Garcia and colleagues combined the Staphylococcal endolysin LysH5 with nisin, in the presence of metal ions. They concluded that LysH5 activity was enhanced in the 
presence of $\mathrm{Ca}^{2+}, \mathrm{Mg}^{2+}$ and $\mathrm{NaCl}$ but inhibited by $\mathrm{Mn}^{2+}$ and $\mathrm{Zn}^{2+}$ [104]. Therefore, the inclusion of ion chelators, such as ethylenediaminetetraacetic acid (EDTA), as excipients could potentially decrease the efficacy of phage or endolysin binding, while an ionic solvent with increased $\mathrm{Ca}^{2+}$ ion concentration could potentially increase the overall level of phage binding [67,144].

\subsection{Formulation Against Spores and Biofilms}

When presented with unfavorable conditions, such as depleted nutrient sources, and the presence of antimicrobials, some bacterial species have developed strategies to enable them to persist in the environment. These include the ability to form bacterial endospores as is the case with Bacillus and Clostridia species and the ability to produce bacterial biofilms which are considered more resistant to antibiotic and chemical decontamination treatments compared to their vegetative counterparts $[145,146]$. Phages and endolysins from these two bacterial species have been reviewed elsewhere in more detail [147].

Bacterial spores could be targeted with germinant compounds in order to convert the potentially-resistant spore form into the susceptible vegetative state [148], while extracellular capsules which prevent phage infections could be degraded through the addition of recombinant enzymes [17,149], although there is some suggestion that endolysins may be capable of interacting with the endospore [150]. However, it is important to note that the induction of spore germination in human therapeutics would be highly dangerous and unethical, but for non-clinical applications (particularly wide-area decontamination), the induction of spore germination has resulted in enhanced bacterial destruction $[146,151]$. The type of germinant that would be required would vary between bacterial species, with bile salts commonly used for Clostridia species and a combination of L-alanine and inosine effective in Bacillus [148,152-154]. However, additional research into the efficacy and interactions between phages or phage derived antimicrobial enzymes is still required.

Bacterial biofilms represent a serious healthcare issue accounting for up to $80 \%$ of all microbial infections and are often prevalent in a number of chronic conditions. Such conditions, including cystic fibrosis lung infections and chronic burns, are often poly-microbial in nature [155-157]. In these conditions, the biofilm acts in a variety of different ways which can result in the failure of antibiotic treatment [158]. Biofilms can act as a permeability barrier to both antibiotics and antimicrobial metals, as well as to non-specific immune mechanisms [159-162]. While phages are capable of reaching bacteria within biofilms, the production of exopolymeric substances (EPS) can act as a non-specific barrier to phages, reducing the amount that are able to infect susceptible cells. In response to this, some phages possess EPS de-polymerases which can disrupt biofilms (Table 6). Although these enzymes are not directly antimicrobial, they could potentially increase the amount of phages that can reach bacterial targets by degrading EPS, while disrupting the overall biofilm structure and exposing persister cells [163-165]. The development of phage derived EPS de-polymerases may initially be more inefficient due to the costs associated with research and regulatory approval and the use of traditional approved mucolytic agents such as ambroxol or acetylcysteine may prove more financially viable $[166,167]$.

Table 6. Examples of bacteriophage-derived depolymerase enzymes.

\begin{tabular}{|c|c|c|c|}
\hline Bacterial Target & Phage & Summary & Reference \\
\hline \multirow[b]{2}{*}{ A. baumannii } & Petty & $\begin{array}{l}\text { Enzymatic activity from Dpo1 depolymerase protein from Petty degraded } \\
\text { purified EPS from A. baumannii }\end{array}$ & [168] \\
\hline & $\varphi \mathrm{AB} 6$ & $\begin{array}{l}\varphi \mathrm{AB} 6 \text { has a polysaccharide depolymerase degraded A. baumannii EPS and } \\
\text { is a component of the phage tail fiber that determines host specificity }\end{array}$ & [169] \\
\hline \multirow[b]{2}{*}{ E. coli } & VB_EcoM_ECOO78 & $\begin{array}{l}\text { Dpo42 prevented biofilm formation in } 15 \text { clinical E. coli strains and reduced } \\
\text { biofilm formation when compared to negative controls }\end{array}$ & {$[170]$} \\
\hline & $\mathrm{K} 1, \mathrm{~K} 5$, and $\mathrm{K} 30$ & $\begin{array}{l}\text { - Addition of polymerase increased mouse survival at five days post } \\
\text { bacterial exposure in a concentration dependent manner } \\
\text { - } \quad \begin{array}{l}\text { Differences in survival were observed between different } \\
\text { depolymerase types }\end{array} \\
\text { - } \quad \begin{array}{l}\text { Depolymerase in combination with serum enhanced bacterial killing } \\
\text { compared to controls }\end{array}\end{array}$ & {$[171]$} \\
\hline
\end{tabular}


Table 6. Cont.

\begin{tabular}{|c|c|c|c|}
\hline Bacterial Target & Phage & Summary & Reference \\
\hline \multirow{3}{*}{ Klebsiella } & $\varphi \mathrm{K} 64-1$ & $\begin{array}{l}\text { Phage encoded } 8 \text { putative depolymerases } \\
\text { Production of phage mutants that did not encode putative depolymerases } \\
\text { eliminated lytic activity }\end{array}$ & [172] \\
\hline & K5-2 and K5-4 & $\begin{array}{l}\text { - } \quad \text { Each phage encodes for two different capsule depolymerases that } \\
\text { allows them to replicate on certain Klebsiella strains } \\
\text { - } \quad \text { K5-2 causes spots on seven capsular types of Klebsiella } \\
\text { - } \quad \text { K5-4 increased survival of mice treated with K. pneumoniae K5 strain }\end{array}$ & [173] \\
\hline & KP32 & $\begin{array}{l}\text { Tail tubular protein A (TTPA), a structural tail protein of KP32, exhibits } \\
\text { lytic activity towards EPS. TTPA can be regarded as a dual function } \\
\text { macromolecule with both structural and enzymatic activities }\end{array}$ & [174] \\
\hline Erwinia amylovora & L1 & $\begin{array}{l}\text { DpoL1 is required for L1 uptake and specifically binds to, and degrades, } E \text {. } \\
\text { amylovora EPS by cleaving the amylovoran galactose backbone }\end{array}$ & [175] \\
\hline
\end{tabular}

Table 7. Examples of modified-release dosage of phages or phage-derived antimicrobial enzymes. HPMC: Hydroxypropylmethylcellulose; PNIPAM: Poly ( $N$-isopropylacrylamide).

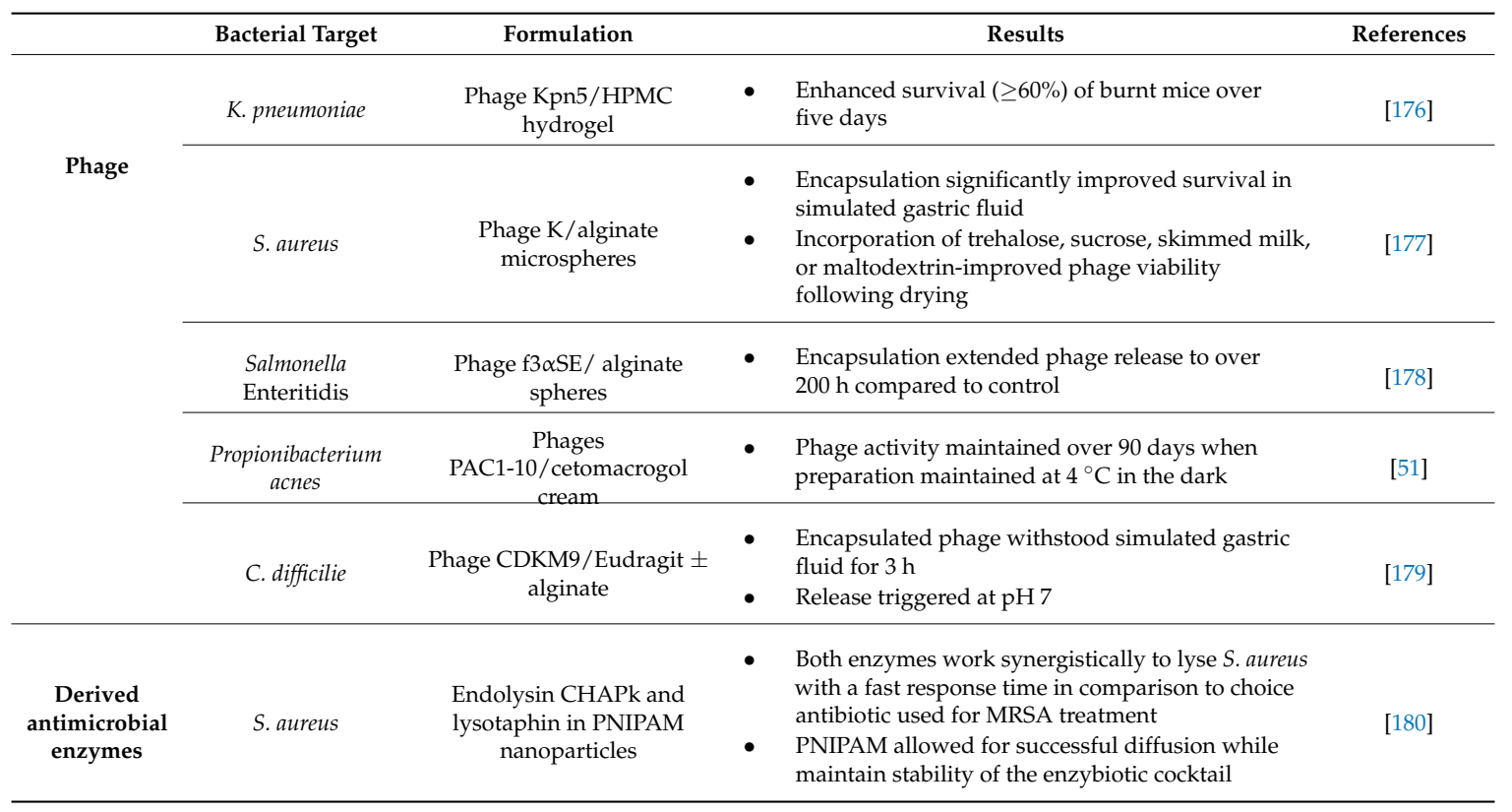

\section{Enhancing Storage, Dosing, and Delivery}

Any final formulation involving whole phages, phage-derived antimicrobial enzymes, and adjunct components will have to consider the intended application. How such therapeutics are stored and delivered could influence the potential shelf life, persistence in vivo, and the overall efficacy of the phage and non-phage adjuncts $[13,181,182]$. Although clinical and non-clinical applications share some of the same requirements for storage and delivery (e.g., long shelf life at ambient temperatures), which would enable research to be carried out more effectively, it is likely that each treatment area will possess unique requirements.

The susceptibility of whole phages to environmental stresses ( $\mathrm{pH}$, temperature, humidity, etc.) can be highly variable under non-formulated conditions, although most can tolerate relatively wide $\mathrm{pH}$ and temperature ranges $[14,126,183-186]$. These varying degrees of susceptibility will have an important impact, not only during manufacturing, formulation, and routine storage, but also during therapeutic applications, particularly when encountering a hostile environment (e.g., transiting the stomach) [186]. In order to increase the long-term storage of phages, they have been lyophilized in the presence of different sugars for increased stability and allowing delivery in a powdered form, e.g., in metered-dose inhalers [187-189]. Additionally, phages or their derived antimicrobial enzymes 
could be formulated into liquid formulations, but in order to maintain pharmacopeia compliance, preservatives or other compounds may be required to prevent microbial contamination.

As discussed earlier, the overall efficacy of a phage cocktail could be compromised (assuming an immediate application of all phages) as one phage reproduces more efficiently than the other components (e.g., more efficient adsorption and shorter latency period) or as phages compete for binding sites when applied simultaneously. This competition could be reduced by the selection of phages which do not compete with one another in cocktails or applying individual phages at different times initially, as there are also solutions through formulation which could enhance and simplify this process. Modified release dosage allows for drug delivery with a delay from the time of administration or prolonged release and is used for pain management [190-192]. Simple liquid suspensions are most commonly used for topical and oral applications [193-196]. While these suspensions are able to effectively rinse infected wounds as large volumes of suspension can be applied, much of the suspension is lost as it runs off the site of infection. However, for applications which require a surface contact (e.g., food preservation and wound infections), impregnated materials, such as hydrogels (Table 7), are increasingly being researched as these would allow for a constant release of phage or antimicrobial enzyme by maintaining contact with the contaminated area. This could ultimately result in less wastage, but optimization would be required to ensure that an effective dose is delivered.

Encapsulating the phage or derived antimicrobial enzyme within polymer microparticles (Table 7) [177] could also prove beneficial. By encapsulation of biofilm-disrupting compounds, such as ambroxol, which are released prior to the release of the phage, the overall efficacy could be enhanced as they would enable greater penetration into the biofilm layer. Such polymer microparticles have been shown to be able to be triggered into releasing their "drug" components through a variety of triggers, including $\mathrm{pH}$ and temperature, each of which would benefit specific applications (e.g., low temperature release for food preservation and low $\mathrm{pH}$ to survive transit through the gastrointestinal tract) $[179,180]$. Encapsulation of formulations within microfluidic-produced microcapsules would also allow for the production of uniformly-sized particles [179,197], which for inhalational use would mean that specific areas of the lung could be targeted [198]. While for larger scale spray applications (e.g., crop protection), uniformly-sized particles in combination with effective delivery technology could optimize surface coverage [199].

\section{Phage Degradation and Immunogenicity}

There is evidence to suggest that the release of bacterial endotoxins (in particular lipopolysaccharide; LPS) does not increase and that the overall outcome of phage therapy is not compromised due to anti-phage immune responses in phage-treated complex systems [20,137,200-202]. There are still areas in which further research is necessary, as the level and type of immune response encountered is likely to change depending on the therapy approach. For example as an additive to animal feed, where phages would be given over long periods of time, this could result in the development of phage-specific antibodies [35,203]. While the incorporation of immunomodulatory compounds into therapies could be potentially ethically and practically inadvisable, there are a number of anti-LPS compounds (such as lipoamines or some alkaloids) that have been shown to reduce pro-inflammatory responses caused by LPS [204-207]. However, these would need to be tested to determine their ability to work in synergy with phages or their derived antimicrobial enzymes.

An alternative approach would be to mask phages or antimicrobial enzymes from the immune system. Such an approach has been described by Kim et al. This approach involved the pegylation of whole phages and suggest that phage half-life in a mice was increased and exhibited significantly lower levels of IFN- $\gamma$ and IL-6 release [208,209]. However in the case of endolysins, a later study by Resch et al. showed that the pegylation of a Streptococcus pneumoniae specific endolysin (Cpl-1) exhibited significantly lower activity than that of the native enzyme [210].

Within reported human cases within Western hospitals, dosing requirements are often based on the endotoxin content of a phage preparation rather than the phage content in order to maximize 
the amount of phages that can be delivered during a single treatment while meeting regulatory requirements $[87,202]$. It should be noted that some phage clinical trials have provided little information about the overall dosing and concentration of the active phage component [211]. While such studies have shown promise, there is still limited knowledge surrounding the dosing requirements for phages and phage-derived antimicrobial enzymes when applied in vivo as antibiotic alternatives.

\section{Concluding Remarks}

Therapeutics based on whole phages (or their derived antimicrobial proteins) represent an exciting alternative to conventional antibacterial treatments in both clinical and non-clinical scenarios. While for human clinical applications, there are a number of clinical successes reportedly supported by growing in vitro testing and in vivo testing which suggests that whole-phage therapy is viable for a variety of conditions. However, it is important to note that these reported human cases are often on a limited number of patients and have been based on compassionate or magisterial phage usage rather than taking the form of regulated clinical trials $[15,212,213]$. In non-clinical applications, whole phages and endolysins have found some commercial success as food additives to prevent bacterial contamination (Table 1), but phage-based medicines have yet to successfully navigate the clinical approvals process. For whole phages this partly stems from an incompatibility with regulatory processes and the potential need for phage-specific approval pathways. It also reflects a need for increased collaboration between regulators and developers to decide what form phage therapy should take (bespoke or pre-manufactured), the desired outcome of any treatment (prevention or intervention) and the type of regulation that is necessary for widespread implementation (full regulatory approval or compassionate usage only) as for each area different selection criteria could be required.

Currently available commercial products or compassionately-used therapies often contain simple cocktails of phages or phage-derived antimicrobial enzymes (e.g., endolysins) that are, in the majority of cases, applied directly to target areas and contain few, if any, additional components. Indeed, while the development of more complex pharmaceuticals with phages or phage-derived antimicrobial enzymes as their main active ingredients may allow for some of the limitations to be addressed, this is currently understudied. However, it would be necessary to study the pharmacology and secondary effects of such combinations in vitro.

It is unlikely that whole-phage products will become the widespread antibiotic alternative that they are considered to be by some. While the implementation of complex formulations may help to address some of the biologically-imposed limitations of whole-phage treatments, these will come with additional financial costs and also further complicate the already complex nature of phage pharmacology. While the information presented in the current review is not an exhaustive comparison, it is important to note that any complete formulation will likely be the result of tradeoffs designed to maximize benefits and minimize deficiencies.

Acknowledgments: This work was supported by the Olle Engkvist Byggmästare Foundation under grant number 2015/419; and the Swedish Research Council for Environment, Agricultural Sciences and Spatial Planning (FORMAS) coordinated by the Animal Health and Welfare (ANIHWA) project within the European Research Area (ERA-NET) under grant number 221-2015-1894.

Author Contributions: All authors contributed equally to the manuscript.

Conflicts of Interest: The authors declare no conflicts of interest.

\section{References}

1. Van Boeckel, T.P.; Gandra, S.; Ashok, A.; Caudron, Q.; Grenfell, B.T.; Levin, S.A.; Laxminarayan, R. Global antibiotic consumption 2000 to 2010: An analysis of national pharmaceutical sales data. Lancet Infect. Dis. 2014, 14, 742-750. [CrossRef]

2. Van Boeckel, T.P.; Brower, C.; Gilbert, M.; Grenfell, B.T.; Levin, S.A.; Robinson, T.P.; Teillant, A.; Laxminarayan, R. Global trends in antimicrobial use in food animals. Proc. Natl. Acad. Sci. USA 2015, 112, 5649-5654. [CrossRef] [PubMed] 
3. Webber, M.A.; Whitehead, R.N.; Mount, M.; Loman, N.J.; Pallen, M.J.; Piddock, L.J.V. Parallel evolutionary pathways to antibiotic resistance selected by biocide exposure. J. Antimicrob. Chemother. 2015, 70, 2241-2248. [CrossRef] [PubMed]

4. Soumet, C.; Méheust, D.; Pissavin, C.; Le Grandois, P.; Frémaux, B.; Feurer, C.; Le Roux, A.; Denis, M.; Maris, P. Reduced susceptibilities to biocides and resistance to antibiotics in food-associated bacteria following exposure to quaternary ammonium compounds. J. Appl. Microbiol. 2016, 121, 1275-1281. [CrossRef] [PubMed]

5. Ng, K.M.; Ferreyra, J.A.; Higginbottom, S.K.; Lynch, J.B.; Kashyap, P.C.; Gopinath, S.; Naidu, N.; Choudhury, B.; Weimer, B.C.; Monack, D.M.; et al. Microbiota-liberated host sugars facilitate post-antibiotic expansion of enteric pathogens. Nature 2013, 502, 96-99. [CrossRef] [PubMed]

6. Faber, F.; Tran, L.; Byndloss, M.X.; Lopez, C.A.; Velazquez, E.M.; Kerrinnes, T.; Nuccio, S.-P.; Wangdi, T.; Fiehn, O.; Tsolis, R.M.; et al. Host-mediated sugar oxidation promotes post-antibiotic pathogen expansion. Nature 2016, 534, 697-699. [CrossRef] [PubMed]

7. Meader, E.; Mayer, M.J.; Steverding, D.; Carding, S.R.; Narbad, A. Evaluation of bacteriophage therapy to control Clostridium difficile and toxin production in an in vitro human colon model system. Anaerobe 2013, 22, 25-30. [CrossRef] [PubMed]

8. Wang, J.; Gao, Y.; Zhao, F. Phage-bacteria interaction network in human oral microbiome. Environ. Microbiol. 2016, 18, 2143-2158. [CrossRef] [PubMed]

9. Zhao, J.; Liu, Y.; Xiao, C.; He, S.; Yao, H.; Bao, G. Efficacy of Phage Therapy in Controlling Rabbit Colibacillosis and Changes in Cecal Microbiota. Front. Microbiol. 2017, 8. [CrossRef] [PubMed]

10. Abedon, S.T.; Kuhl, S.J.; Blasdel, B.G.; Kutter, E.M. Phage treatment of human infections. Bacteriophage 2011, 1, 66-85. [CrossRef] [PubMed]

11. Viertel, T.M.; Ritter, K.; Horz, H.-P. Viruses versus bacteria-Novel approaches to phage therapy as a tool against multidrug-resistant pathogens. J. Antimicrob. Chemother. 2014, 69, 2326-2336. [CrossRef] [PubMed]

12. Sulakvelidze, A. Using lytic bacteriophages to eliminate or significantly reduce contamination of food by foodborne bacterial pathogens. J. Sci. Food Agric. 2013, 93, 3137-3146. [CrossRef] [PubMed]

13. Cooper, C.J.; Khan Mirzaei, M.; Nilsson, A.S. Adapting Drug Approval Pathways for Bacteriophage-Based Therapeutics. Front. Microbiol. 2016, 7, 1209. [CrossRef] [PubMed]

14. Cooper, I.R. A review of current methods using bacteriophages in live animals, food and animal products intended for human consumption. J. Microbiol. Methods 2016, 130, 38-47. [CrossRef] [PubMed]

15. Totté, J.E.E.; van Doorn, M.B.; Pasmans, S.G.M.A. Successful Treatment of Chronic Staphylococcus aureus-Related Dermatoses with the Topical Endolysin Staphefekt SA.100: A Report of 3 Cases. Case Rep. Dermatol. 2017, 9 , 19-25. [CrossRef] [PubMed]

16. Bryan, D.; El-Shibiny, A.; Hobbs, Z.; Porter, J.; Kutter, E.M. Bacteriophage T4 Infection of Stationary Phase E. coli: Life after Log from a Phage Perspective. Front. Microbiol. 2016, 7. [CrossRef] [PubMed]

17. Negus, D.; Burton, J.; Sweed, A.; Gryko, R.; Taylor, P.W. Poly- $\gamma$-D-Glutamic Acid Capsule Interferes with Lytic Infection of Bacillus anthracis by B. anthracis-Specific Bacteriophages. Appl. Environ. Microbiol. 2013, 79, 714-717. [CrossRef] [PubMed]

18. Barrangou, R.; van der Oost, J. Bacteriophage exclusion, a new defense system. EMBO J. 2015, 34, $134-135$. [CrossRef] [PubMed]

19. Barrangou, R. The roles of CRISPR-Cas systems in adaptive immunity and beyond. Curr. Opin. Immunol. 2015, 32, 36-41. [CrossRef] [PubMed]

20. Górski, A.; Międzybrodzki, R.; Borysowski, J.; Dąbrowska, K.; Wierzbicki, P.; Ohams, M.; Korczak-Kowalska, G.; Olszowska-Zaremba, N.; Łusiak-Szelachowska, M.; Kłak, M.; et al. Phage as a Modulator of Immune Responses: Practical Implications for Phage Therapy. In Advances in Virus Research; Bacteriophages, Part B; Łobocka, M., Szybalski, W., Eds.; Elsevier Science Publishing: Amsterdam, The Netherlands, 2012; Chapter 2, Volume 83, pp. 41-71.

21. Łusiak-Szelachowska, M.; Zaczek, M.; Weber-Dąbrowska, B.; Międzybrodzki, R.; Kłak, M.; Fortuna, W.; Letkiewicz, S.; Rogóż, P.; Szufnarowski, K.; Jończyk-Matysiak, E.; et al. Phage neutralization by sera of patients receiving phage therapy. Viral Immunol. 2014, 27, 295-304. [CrossRef] [PubMed]

22. Nguyen, K.; Simmons, K.; Tatarnikov, I. Co-inoculation of Escherichia coli B23 by T4 and T7 bacteriophages results in competition shown by an overall drop in phage progeny. J. Exp. Microbiol. Immunol. 2014, 18, 156-161. 
23. Bremner, W.; Campbell, T.; Ferera, J.; Zaman, R. Evaluating Double Agar Overlay Assay and Flow Cytometry as Methods for Characterizing Competition between T4 and T7 Bacteriophages in Escherichia coli C600. J. Exp. Microbiol. Immunol. 2016, 20, 69-77.

24. Roach, D.R.; Donovan, D.M. Antimicrobial bacteriophage-derived proteins and therapeutic applications. Bacteriophage 2015, 5. [CrossRef] [PubMed]

25. Endersen, L.; Guinane, C.M.; Johnston, C.; Neve, H.; Coffey, A.; Ross, R.P.; McAuliffe, O.; O’Mahony, J. Genome analysis of Cronobacter phage vB_CsaP_Ss1 reveals an endolysin with potential for biocontrol of Gram-negative bacterial pathogens. J. Gen. Virol. 2015, 96, 463-477. [CrossRef] [PubMed]

26. Linden, S.B.; Zhang, H.; Heselpoth, R.D.; Shen, Y.; Schmelcher, M.; Eichenseher, F.; Nelson, D.C. Biochemical and biophysical characterization of PlyGRCS, a bacteriophage endolysin active against methicillin-resistant Staphylococcus aureus. Appl. Microbiol. Biotechnol. 2015, 99, 741-752. [CrossRef] [PubMed]

27. Oliveira, H.; Vilas Boas, D.; Mesnage, S.; Kluskens, L.D.; Lavigne, R.; Sillankorva, S.; Secundo, F.; Azeredo, J. Structural and Enzymatic Characterization of ABgp46, a Novel Phage Endolysin with Broad Anti-Gram-Negative Bacterial Activity. Front. Microbiol. 2016, 7. [CrossRef] [PubMed]

28. Maciejewska, B.; Olszak, T.; Drulis-Kawa, Z. Applications of bacteriophages versus phage enzymes to combat and cure bacterial infections: An ambitious and also a realistic application? Appl. Microbiol. Biotechnol. 2018, 102, 2563-2581. [CrossRef] [PubMed]

29. Briers, Y.; Lavigne, R. Breaking barriers: Expansion of the use of endolysins as novel antibacterials against Gram-negative bacteria. Future Microbiol. 2015, 10, 377-390. [CrossRef] [PubMed]

30. Rodríguez-Rubio, L.; Gutiérrez, D.; Donovan, D.M.; Martínez, B.; Rodríguez, A.; García, P. Phage lytic proteins: Biotechnological applications beyond clinical antimicrobials. Crit. Rev. Biotechnol. 2016, 36, 542-552. [CrossRef] [PubMed]

31. Song, J.; Xia, F.; Jiang, H.; Li, X.; Hu, L.; Gong, P.; Lei, L.; Feng, X.; Sun, C.; Gu, J.; et al. Identification and characterization of HolGH15: The holin of Staphylococcus aureus bacteriophage GH15. J. Gen. Virol. 2016, 97, 1272-1281. [CrossRef] [PubMed]

32. Zhang, W.Y. A benefit-risk assessment of caffeine as an analgesic adjuvant. Drug Saf. 2001, 24, 1127-1142. [CrossRef] [PubMed]

33. Elder, D.P.; Kuentz, M.; Holm, R. Pharmaceutical excipients—Quality, regulatory and biopharmaceutical considerations. Eur. J. Pharm. Sci. 2016, 87, 88-99. [CrossRef] [PubMed]

34. Pasquet, J.; Chevalier, Y.; Couval, E.; Bouvier, D.; Bolzinger, M.-A. Zinc oxide as a new antimicrobial preservative of topical products: Interactions with common formulation ingredients. Int. J. Pharm. 2015, 479, 88-95. [CrossRef] [PubMed]

35. Garcia-Fernandez, M.J.; Tabary, N.; Chai, F.; Cazaux, F.; Blanchemain, N.; Flament, M.-P.; Martel, B. New multifunctional pharmaceutical excipient in tablet formulation based on citric acid-cyclodextrin polymer. Int. J. Pharm. 2016, 511, 913-920. [CrossRef] [PubMed]

36. Basavaraj, S.; Betageri, G.V. Can formulation and drug delivery reduce attrition during drug discovery and development-Review of feasibility, benefits and challenges. Acta Pharm. Sin. B 2014, 4, 3-17. [CrossRef] [PubMed]

37. Intralytix, Inc. ListShield ${ }^{\mathrm{TM}}$. Available online: http://www.intralytix.com/files/prod/01LP/01LP-Desc.pdf (accessed on 16 March 2018).

38. Intralytix, Inc. EcoShield ${ }^{\mathrm{TM}}$. Available online: http://www.intralytix.com/files/prod/07EP/07EP-Desc.pdf (accessed on 16 March 2018).

39. Intralytix, Inc. SalmoFresh ${ }^{\mathrm{TM}}$. Available online: http://www.intralytix.com/files/prod/02SP/02SP-Desc. pdf (accessed on 16 March 2018).

40. Intralytix, Inc. ShigaShield ${ }^{\mathrm{TM}}$. Available online: http://www.intralytix.com/index.php?page=prod\&id=8 (accessed on 16 March 2018).

41. Product Info-AgriPhage ${ }^{\mathrm{TM}}$. Available online: https://www.agriphage.com/product-info/ (accessed on 20 March 2018).

42. Phagoburn: Evaluation of phage therapy for the treatment of burn wound infections. Available online: http:/ / www.phagoburn.eu/ (accessed on 20 March 2018).

43. ClinicalTrials.gov. Evaluation of Phage Therapy for the Treatment of Escherichia Coli and Pseudomonas Aeruginosa Wound Infections in Burned Patients. Available online: https:/ / clinicaltrials.gov/ct2/show / NCT02116010 (accessed on 19 December 2017). 
44. PneumoPhage: A Collaborative Research Project for the Development of an Effective Phage Therapy Treatment against Respiratory Tract Infections. Available online: http:/ / www.pherecydes-pharma.com/ pneumophage.html (accessed on 20 March 2018).

45. PHOSA: A Collaborative Research Project for the Development of an Innovative Phage Therapy Treatment against Bone/Joint and Diabetic foot Ulcer Infections. Available online: http:/ / www.pherecydes-pharma. com/phosa-collaborative-project.html (accessed on 20 March 2018).

46. AmpliPhi Bioscineces Company: Pipeline. Available online: http://www.ampliphibio.com/pipeline/ (accessed on 20 March 2018).

47. Staphefekt ${ }^{\mathrm{TM}}$ Technology. Available online: https://www.staphefekt.com/en/content/technology (accessed on 20 March 2018).

48. ClinicalTrials.gov. The Effect of Gladskin on Disease Severity and the Skin Microbiome, Including Staphylococcus Aureus, in Patients with Atopic Dermatitis. Available online: https://clinicaltrials.gov/ct2/ show / NCT02840955 (accessed on 20 March 2018).

49. CF-301: ContraFect Corporation (CFRX). Available online: https://www.contrafect.com/pipeline/cf-301 (accessed on 20 March 2018).

50. World Health Organization. Guidelines on the Nonclinical Evaluation of Vaccine Adjuvants and Adjuvanted Vaccines; World Health Organization: Geneva, Switzerland, 2013.

51. Brown, D.F.J.; Wootton, M.; Howe, R.A. Antimicrobial susceptibility testing breakpoints and methods from BSAC to EUCAST. J. Antimicrob. Chemother. 2016, 71, 3-5. [CrossRef] [PubMed]

52. Jorgensen, J.H.; Turnidge, J.D. Susceptibility Test Methods: Dilution and Disk Diffusion Methods. In Manual of Clinical Microbiology, 11th ed.; American Society of Microbiology: Washington, DC, USA, 2015; pp. 1253-1273. [CrossRef]

53. Carlson, K. Working with bacteriophages: Common techniques and methodological approaches. In Bacteriophages: Biology and Applications; Kutter, E., Sulakvelidze, A., Eds.; CRC Press: Boca Raton, FL, USA, 2005; ISBN 978-0-8493-1336-3.

54. Hyman, P.; Abedon, S.T. Practical Methods for Determining Phage Growth Parameters. In Bacteriophages; Methods in Molecular Biology ${ }^{\mathrm{TM}}$; Humana Press: New York, NY, USA, 2009; pp. 175-202, ISBN 978-1-58829-682-5.

55. Kutter, E. Phage Host Range and Efficiency of Plating. In Bacteriophages; Methods in Molecular Biology ${ }^{\mathrm{TM}}$; Humana Press: New York, NY, USA, 2009; pp. 141-149, ISBN 978-1-58829-682-5.

56. Mirzaei, M.K.; Nilsson, A.S. Isolation of Phages for Phage Therapy: A Comparison of Spot Tests and Efficiency of Plating Analyses for Determination of Host Range and Efficacy. PLoS ONE 2015, 10, e0118557. [CrossRef] [PubMed]

57. Gill, J.J.; Hyman, P. Phage choice, isolation, and preparation for phage therapy. Curr. Pharm. Biotechnol. 2010, 11, 2-14. [CrossRef] [PubMed]

58. Weber-Dąbrowska, B.; Jończyk-Matysiak, E.; Żaczek, M.; Łobocka, M.; Łusiak-Szelachowska, M.; Górski, A. Bacteriophage Procurement for Therapeutic Purposes. Front. Microbiol. 2016, 7. [CrossRef] [PubMed]

59. Pimchan, T.; Cooper, C.J.; Eumkeb, G.; Nilsson, A.S. In vitro activity of a combination of bacteriophages and antimicrobial plant extracts. Lett. Appl. Microbiol. 2018, 66, 182-187. [CrossRef] [PubMed]

60. Oliveira, A.; Ribeiro, H.G.; Silva, A.C.; Silva, M.D.; Sousa, J.C.; Rodrigues, C.F.; Melo, L.D.R.; Henriques, A.F.; Sillankorva, S. Synergistic Antimicrobial Interaction between Honey and Phage against Escherichia coli Biofilms. Front. Microbiol. 2017, 8. [CrossRef] [PubMed]

61. Gyotoku, T.; Aurelian, L.; Neurath, A.R. Cellulose acetate phthalate (CAP): An "inactive" pharmaceutical excipient with antiviral activity in the mouse model of genital herpesvirus infection. Antivir. Chem. Chemother. 1999, 10, 327-332. [CrossRef] [PubMed]

62. Heselpoth, R.D.; Owens, J.M.; Nelson, D.C. Quantitative analysis of the thermal stability of the gamma phage endolysin PlyG: A biophysical and kinetic approach to assaying therapeutic potential. Virology 2015, 477, 125-132. [CrossRef] [PubMed]

63. White, R.L.; Burgess, D.S.; Manduru, M.; Bosso, J.A. Comparison of three different in vitro methods of detecting synergy: Time-kill, checkerboard, and E test. Antimicrob. Agents Chemother. 1996, 40, 1914-1918. [PubMed]

64. Hsieh, M.H.; Yu, C.M.; Yu, V.L.; Chow, J.W. Synergy assessed by checkerboard. A critical analysis. Diagn. Microbiol. Infect. Dis. 1993, 16, 343-349. [CrossRef] 
65. Nilsson, A.S. Phage therapy—Constraints and possibilities. Ups. J. Med. Sci. 2014, 119, 192-198. [CrossRef] [PubMed]

66. GRAS Notice (GRN) No. 672. Available online: https://www.accessdata.fda.gov/scripts/fdcc/?set= grasnotices\&id=672 (accessed on 19 March 2018).

67. Strickley, R.G. Solubilizing Excipients in Oral and Injectable Formulations. Pharm. Res. 2004, 21, $201-230$. [CrossRef] [PubMed]

68. Pirnay, J.-P.; Merabishvili, M.; Raemdonck, H.V.; Vos, D.D.; Verbeken, G. Bacteriophage Production in Compliance with Regulatory Requirements. In Bacteriophage Therapy; Methods in Molecular Biology; Humana Press: New York, NY, USA, 2018; pp. 233-252, ISBN 978-1-4939-7394-1.

69. Rathore, A.S.; Winkle, H. Quality by design for biopharmaceuticals. Nat. Biotechnol. 2009, $27,26-34$. [CrossRef] [PubMed]

70. Fauconnier, A. Guidelines for Bacteriophage Product Certification. Methods Mol. Biol. 2018, 1693, $253-268$. [CrossRef] [PubMed]

71. European Directorate for the Quality of Medicines (EDQM). European Pharmacopoeia, 7th ed.; EDQM: Strasbourg, France, 2010; pp. 163-167, 519-520.

72. Merabishvili, M.; Pirnay, J.-P.; Vos, D.D. Guidelines to Compose an Ideal Bacteriophage Cocktail. In Bacteriophage Therapy; Methods in Molecular Biology; Humana Press: New York, NY, USA, 2018; pp. 99-110, ISBN 978-1-4939-7394-1.

73. Levin, B.R.; Bull, J.J. Population and evolutionary dynamics of phage therapy. Nat. Rev. Microbiol. 2004, 2, 166-173. [CrossRef] [PubMed]

74. Shao, Y.; Wang, I.-N. Bacteriophage Adsorption Rate and Optimal Lysis Time. Genetics 2008, 180, 471-482. [CrossRef] [PubMed]

75. Chan, B.K.; Abedon, S.T.; Loc-Carrillo, C. Phage cocktails and the future of phage therapy. Future Microbiol. 2013, 8, 769-783. [CrossRef] [PubMed]

76. Schmerer, M.; Molineux, I.J.; Bull, J.J. Synergy as a rationale for phage therapy using phage cocktails. PeerJ 2014, 2. [CrossRef] [PubMed]

77. Pereira, C.; Moreirinha, C.; Lewicka, M.; Almeida, P.; Clemente, C.; Cunha, Â.; Delgadillo, I.; Romalde, J.L.; Nunes, M.L.; Almeida, A. Bacteriophages with potential to inactivate Salmonella Typhimurium: Use of single phage suspensions and phage cocktails. Virus Res. 2016, 220, 179-192. [CrossRef] [PubMed]

78. Bull, J.J.; Gill, J.J. The habits of highly effective phages: Population dynamics as a framework for identifying therapeutic phages. Front. Microbiol. 2014, 5. [CrossRef] [PubMed]

79. Wu, S.; Zachary, E.; Wells, K.; Loc-Carrillo, C. Phage Therapy: Future Inquiries. Postdoc J. J. Postdr. Res. Postdr. Aff. 2013, 1, 24-35. [CrossRef]

80. Oechslin, F.; Piccardi, P.; Mancini, S.; Gabard, J.; Moreillon, P.; Entenza, J.M.; Resch, G.; Que, Y.-A. Synergistic Interaction between Phage Therapy and Antibiotics Clears Pseudomonas Aeruginosa Infection in Endocarditis and Reduces Virulence. J. Infect. Dis. 2017, 215, 703-712. [CrossRef] [PubMed]

81. Chhibber, S.; Shukla, A.; Kaur, S. Transfersomal Phage Cocktail Is an Effective Treatment against Methicillin-Resistant Staphylococcus aureus-Mediated Skin and Soft Tissue Infections. Antimicrob. Agents Chemother. 2017, 61, e02146-16. [CrossRef] [PubMed]

82. Fu, W.; Forster, T.; Mayer, O.; Curtin, J.J.; Lehman, S.M.; Donlan, R.M. Bacteriophage Cocktail for the Prevention of Biofilm Formation by Pseudomonas aeruginosa on Catheters in an In Vitro Model System. Antimicrob. Agents Chemother. 2010, 54, 397-404. [CrossRef] [PubMed]

83. Heller, K.; Braun, V. Polymannose O-antigens of Escherichia coli, the binding sites for the reversible adsorption of bacteriophage T5+ via the L-shaped tail fibers. J. Virol. 1982, 41, 222-227. [PubMed]

84. Wang, J.; Hofnung, M.; Charbit, A. The C-Terminal Portion of the Tail Fiber Protein of Bacteriophage Lambda Is Responsible for Binding to LamB, Its Receptor at the Surface of Escherichia coli K-12. J. Bacteriol. 2000, 182, 508-512. [CrossRef] [PubMed]

85. Loessner, M.J.; Kramer, K.; Ebel, F.; Scherer, S. C-terminal domains of Listeria monocytogenes bacteriophage murein hydrolases determine specific recognition and high-affinity binding to bacterial cell wall carbohydrates. Mol. Microbiol. 2002, 44, 335-349. [CrossRef] [PubMed]

86. Wright, A.; Hawkins, C.H.; Anggård, E.E.; Harper, D.R. A controlled clinical trial of a therapeutic bacteriophage preparation in chronic otitis due to antibiotic-resistant Pseudomonas aeruginosa; a preliminary report of efficacy. Clin. Otolaryngol. 2009, 34, 349-357. [CrossRef] [PubMed] 
87. Schooley, R.T.; Biswas, B.; Gill, J.J.; Hernandez-Morales, A.; Lancaster, J.; Lessor, L.; Barr, J.J.; Reed, S.L.; Rohwer, F.; Benler, S.; et al. Development and Use of Personalized Bacteriophage-Based Therapeutic Cocktails To Treat a Patient with a Disseminated Resistant Acinetobacter baumannii Infection. Antimicrob. Agents Chemother. 2017, 61. [CrossRef] [PubMed]

88. Gu, J.; Liu, X.; Li, Y.; Han, W.; Lei, L.; Yang, Y.; Zhao, H.; Gao, Y.; Song, J.; Lu, R.; et al. A Method for Generation Phage Cocktail with Great Therapeutic Potential. PLoS ONE 2012, 7, e31698. [CrossRef] [PubMed]

89. Miller, R.W.; Skinner, E.J.; Sulakvelidze, A.; Mathis, G.F.; Hofacre, C.L. Bacteriophage therapy for control of necrotic enteritis of broiler chickens experimentally infected with Clostridium perfringens. Avian Dis. 2010, 54, 33-40. [CrossRef] [PubMed]

90. Breyne, K.; Honaker, R.W.; Hobbs, Z.; Richter, M.; Żaczek, M.; Spangler, T.; Steenbrugge, J.; Lu, R.; Kinkhabwala, A.; Marchon, B.; et al. Efficacy and Safety of a Bovine-Associated Staphylococcus aureus Phage Cocktail in a Murine Model of Mastitis. Front. Microbiol. 2017, 8. [CrossRef] [PubMed]

91. Daikos, G.L.; Tsaousi, S.; Tzouvelekis, L.S.; Anyfantis, I.; Psichogiou, M.; Argyropoulou, A.; Stefanou, I.; Sypsa, V.; Miriagou, V.; Nepka, M.; et al. Carbapenemase-Producing Klebsiella pneumoniae Bloodstream Infections: Lowering Mortality by Antibiotic Combination Schemes and the Role of Carbapenems. Antimicrob. Agents Chemother. 2014, 58, 2322-2328. [CrossRef] [PubMed]

92. Paul, M.; Carmeli, Y.; Durante-Mangoni, E.; Mouton, J.W.; Tacconelli, E.; Theuretzbacher, U.; Mussini, C.; Leibovici, L. Combination therapy for carbapenem-resistant Gram-negative bacteria. J. Antimicrob. Chemother. 2014, 69, 2305-2309. [CrossRef] [PubMed]

93. Kern, W.V.; Marchetti, O.; Drgona, L.; Akan, H.; Aoun, M.; Akova, M.; de Bock, R.; Paesmans, M.; Viscoli, C.; Calandra, T. Oral antibiotics for fever in low-risk neutropenic patients with cancer: A double-blind, randomized, multicenter trial comparing single daily moxifloxacin with twice daily ciprofloxacin plus amoxicillin/clavulanic acid combination therapy_EORTC infectious diseases group trial XV. J. Clin. Oncol. 2013, 31, 1149-1156. [CrossRef] [PubMed]

94. López-Cortés, L.E.; Cisneros, J.M.; Fernández-Cuenca, F.; Bou, G.; Tomás, M.; Garnacho-Montero, J.; Pascual, A.; Martínez-Martínez, L.; Vila, J.; Pachón, J.; et al. Monotherapy versus combination therapy for sepsis due to multidrug-resistant Acinetobacter baumannii: Analysis of a multicentre prospective cohort. J. Antimicrob. Chemother. 2014, 69, 3119-3126. [CrossRef] [PubMed]

95. Davis, J.S.; Sud, A.; O'Sullivan, M.V.N.; Robinson, J.O.; Ferguson, P.E.; Foo, H.; van Hal, S.J.; Ralph, A.P.; Howden, B.P.; Binks, P.M.; et al. Combination of Vancomycin and $\beta$-Lactam Therapy for Methicillin-Resistant Staphylococcus aureus Bacteremia: A Pilot Multicenter Randomized Controlled Trial. Clin. Infect. Dis. 2016, 62, 173-180. [CrossRef] [PubMed]

96. Vestergaard, M.; Paulander, W.; Marvig, R.L.; Clasen, J.; Jochumsen, N.; Molin, S.; Jelsbak, L.; Ingmer, H.; Folkesson, A. Antibiotic combination therapy can select for broad-spectrum multidrug resistance in Pseudomonas aeruginosa. Int. J. Antimicrob. Agents 2016, 47, 48-55. [CrossRef] [PubMed]

97. Ryan, E.M.; Alkawareek, M.Y.; Donnelly, R.F.; Gilmore, B.F. Synergistic phage-antibiotic combinations for the control of Escherichia coli biofilms in vitro. FEMS Immunol. Med. Microbiol. 2012, 65, 395-398. [CrossRef] [PubMed]

98. Knezevic, P.; Curcin, S.; Aleksic, V.; Petrusic, M.; Vlaski, L. Phage-antibiotic synergism: A possible approach to combatting Pseudomonas aeruginosa. Res. Microbiol. 2013, 164, 55-60. [CrossRef] [PubMed]

99. Kamal, F.; Dennis, J.J. Burkholderia cepacia Complex Phage-Antibiotic Synergy (PAS): Antibiotics Stimulate Lytic Phage Activity. Appl. Environ. Microbiol. 2015, 81, 1132-1138. [CrossRef] [PubMed]

100. Tazzyman, S.J.; Hall, A.R. Lytic phages obscure the cost of antibiotic resistance in Escherichia coli. ISME J. 2015, 9, 809-820. [CrossRef] [PubMed]

101. Chan, B.K.; Sistrom, M.; Wertz, J.E.; Kortright, K.E.; Narayan, D.; Turner, P.E. Phage selection restores antibiotic sensitivity in MDR Pseudomonas aeruginosa. Sci. Rep. 2016, 6, 26717. [CrossRef] [PubMed]

102. Becker, S.C.; Foster-Frey, J.; Donovan, D.M. The phage K lytic enzyme LysK and lysostaphin act synergistically to kill MRSA. FEMS Microbiol. Lett. 2008, 287, 185-191. [CrossRef] [PubMed]

103. Schuch, R.; Lee, H.M.; Schneider, B.C.; Sauve, K.L.; Law, C.; Khan, B.K.; Rotolo, J.A.; Horiuchi, Y.; Couto, D.E.; Raz, A.; et al. Combination Therapy With Lysin CF-301 and Antibiotic Is Superior to Antibiotic Alone for Treating Methicillin-Resistant Staphylococcus aureus-Induced Murine Bacteremia. J. Infect. Dis. 2014. [CrossRef] [PubMed] 
104. García, P.; Martínez, B.; Rodríguez, L.; Rodríguez, A. Synergy between the phage endolysin LysH5 and nisin to kill Staphylococcus aureus in pasteurized milk. Int. J. Food Microbiol. 2010, 141, 151-155. [CrossRef] [PubMed]

105. Johnson, L.S.; MacDougall, C.; Trivedi, K.K. The Legislative Momentum of Antimicrobial Stewardship: The US Perspective. Curr. Treat. Options Infect. Dis. 2016, 2, 93-101. [CrossRef]

106. Barlam, T.F.; Cosgrove, S.E.; Abbo, L.M.; MacDougall, C.; Schuetz, A.N.; Septimus, E.J.; Srinivasan, A.; Dellit, T.H.; Falck-Ytter, Y.T.; Fishman, N.O.; et al. Implementing an Antibiotic Stewardship Program: Guidelines by the Infectious Diseases Society of America and the Society for Healthcare Epidemiology of America. Clin. Infect. Dis. 2016, 62, e51-e77. [CrossRef] [PubMed]

107. Speksnijder, D.C.; Mevius, D.J.; Bruschke, C.J.M.; Wagenaar, J. A. Reduction of Veterinary Antimicrobial Use in the Netherlands. The Dutch Success Model. Zoonoses Public Health 2015, 62, 79-87. [CrossRef] [PubMed]

108. Brown, D.G.; Lister, T.; May-Dracka, T.L. New natural products as new leads for antibacterial drug discovery. Bioorg. Med. Chem. Lett. 2014, 24, 413-418. [CrossRef] [PubMed]

109. Harvey, A.L.; Edrada-Ebel, R.; Quinn, R.J. The re-emergence of natural products for drug discovery in the genomics era. Nat. Rev. Drug Discov. 2015, 14, 111-129. [CrossRef] [PubMed]

110. Pettus, K.; Sharpe, S.; Papp, J.R. In Vitro Assessment of Dual Drug Combinations to Inhibit Growth of Neisseria gonorrhoeae. Antimicrob. Agents Chemother. 2015, 59, 2443-2445. [CrossRef] [PubMed]

111. Toledo, P.V.M.; Aranha Junior, A.A.; Arend, L.N.; Ribeiro, V.; Zavascki, A.P.; Tuon, F.F. Activity of antimicrobial combinations against KPC-2-producing Klebsiella pneumoniae in a rat model and time-kill assay. Antimicrob. Agents Chemother. 2015, 59, 4301-4304. [CrossRef] [PubMed]

112. Abbreviations. Antibiotic \& Antimicrobial Resistance Surveillance. Available online: http://www.bsacsurv. org/science/antimicrobials/ (accessed on 20 March 2018).

113. Torres-Barceló, C.; Arias-Sánchez, F.I.; Vasse, M.; Ramsayer, J.; Kaltz, O.; Hochberg, M.E. A Window of Opportunity to Control the Bacterial Pathogen Pseudomonas aeruginosa Combining Antibiotics and Phages. PLoS ONE 2014, 9, e106628. [CrossRef] [PubMed]

114. Comeau, A.M.; Tétart, F.; Trojet, S.N.; Prère, M.-F.; Krisch, H.M. Phage-Antibiotic Synergy (PAS): $\beta$-Lactam and Quinolone Antibiotics Stimulate Virulent Phage Growth. PLoS ONE 2007, 2, e799. [CrossRef] [PubMed]

115. Verma, V.; Harjai, K.; Chhibber, S. Restricting ciprofloxacin-induced resistant variant formation in biofilm of Klebsiella pneumoniae B5055 by complementary bacteriophage treatment. J. Antimicrob. Chemother. 2009, 64, 1212-1218. [CrossRef] [PubMed]

116. Chhibber, S.; Gupta, P.; Kaur, S. Bacteriophage as effective decolonising agent for elimination of MRSA from anterior nares of BALB/c mice. BMC Microbiol. 2014, 14, 212. [CrossRef] [PubMed]

117. Djurkovic, S.; Loeffler, J.M.; Fischetti, V.A. Synergistic Killing of Streptococcus pneumoniae with the Bacteriophage Lytic Enzyme Cpl-1 and Penicillin or Gentamicin Depends on the Level of Penicillin Resistance. Antimicrob. Agents Chemother. 2005, 49, 1225-1228. [CrossRef] [PubMed]

118. Thummeepak, R.; Kitti, T.; Kunthalert, D.; Sitthisak, S. Enhanced Antibacterial Activity of Acinetobacter baumannii Bacteriophage ØАВР-01 Endolysin (LysABP-01) in Combination with Colistin. Front. Microbiol. 2016, 7. [CrossRef] [PubMed]

119. Ibarra-Sánchez, L.A.; Van Tassell, M.L.; Miller, M.J. Antimicrobial behavior of phage endolysin PlyP100 and its synergy with nisin to control Listeria monocytogenes in Queso Fresco. Food Microbiol. 2018, 72, 128-134. [CrossRef] [PubMed]

120. Chhibber, S.; Nag, D.; Bansal, S. Inhibiting biofilm formation by Klebsiella pneumoniae B5055 using an iron antagonizing molecule and a bacteriophage. BMC Microbiol. 2013, 13, 174. [CrossRef] [PubMed]

121. Viazis, S.; Akhtar, M.; Feirtag, J.; Diez-Gonzalez, F. Reduction of Escherichia coli O157:H7 viability on leafy green vegetables by treatment with a bacteriophage mixture and trans-cinnamaldehyde. Food Microbiol. 2011, 28, 149-157. [CrossRef] [PubMed]

122. Chibeu, A.; Agius, L.; Gao, A.; Sabour, P.M.; Kropinski, A.M.; Balamurugan, S. Efficacy of bacteriophage LISTEX ${ }^{\mathrm{TM}}$ P100 combined with chemical antimicrobials in reducing Listeria monocytogenes in cooked turkey and roast beef. Int. J. Food Microbiol. 2013, 167, 208-214. [CrossRef] [PubMed]

123. Chang, Y.; Yoon, H.; Kang, D.-H.; Chang, P.-S.; Ryu, S. Endolysin LysSA97 is synergistic with carvacrol in controlling Staphylococcus aureus in foods. Int. J. Food Microbiol. 2017, 244, 19-26. [CrossRef] [PubMed] 
124. Misiou, O.; van Nassau, T.J.; Lenz, C.A.; Vogel, R.F. The preservation of Listeria-critical foods by a combination of endolysin and high hydrostatic pressure. Int. J. Food Microbiol. 2018, 266, 355-362. [CrossRef] [PubMed]

125. Van Nassau, T.J.; Lenz, C.A.; Scherzinger, A.S.; Vogel, R.F. Combination of endolysins and high pressure to inactivate Listeria monocytogenes. Food Microbiol. 2017, 68, 81-88. [CrossRef] [PubMed]

126. Oliveira, H.; Thiagarajan, V.; Walmagh, M.; Sillankorva, S.; Lavigne, R.; Neves-Petersen, M.T.; Kluskens, L.D.; Azeredo, J. A Thermostable Salmonella Phage Endolysin, Lys68, with Broad Bactericidal Properties against Gram-Negative Pathogens in Presence of Weak Acids. PLoS ONE 2014, 9, e108376. [CrossRef] [PubMed]

127. Cooper, R. Honey as an Effective Antimicrobial Treatment for Chronic Wounds: Is There a Place for It in Modern Medicine? Available online: https:/ / www.dovepress.com/honey-as-an-effective-antimicrobialtreatment-for-chronic-wounds-is-th-peer-reviewed-fulltext-article-CWCMR (accessed on 19 March 2018).

128. Halstead, F.D.; Webber, M.A.; Rauf, M.; Burt, R.; Dryden, M.; Oppenheim, B.A. In vitro activity of an engineered honey, medical-grade honeys, and antimicrobial wound dressings against biofilm-producing clinical bacterial isolates. J. Wound Care 2016, 25, 93-102. [CrossRef] [PubMed]

129. Holland, L.C.; Norris, J.M. Medical grade honey in the management of chronic venous leg ulcers. Int. J. Surg. 2015, 20, 17-20. [CrossRef] [PubMed]

130. El-Kased, R.F.; Amer, R.I.; Attia, D.; Elmazar, M.M. Honey-based hydrogel: In vitro and comparative In vivo evaluation for burn wound healing. Sci. Rep. 2017, 7. [CrossRef] [PubMed]

131. Hillitt, K.L.; Jenkins, R.E.; Spiller, O.B.; Beeton, M.L. Antimicrobial activity of Manuka honey against antibiotic-resistant strains of the cell wall-free bacteria Ureaplasma parvum and Ureaplasma urealyticum. Lett. Appl. Microbiol. 2016, 64, 198-202. [CrossRef] [PubMed]

132. Taormina, P.J.; Niemira, B.A.; Beuchat, L.R. Inhibitory activity of honey against foodborne pathogens as influenced by the presence of hydrogen peroxide and level of antioxidant power. Int. J. Food Microbiol. 2001, 69, 217-225. [CrossRef]

133. Kwakman Paulus, H.S.; Zaat Sebastian, A.J. Antibacterial components of honey. IUBMB Life 2012, 64, 48-55. [CrossRef] [PubMed]

134. Cooper, R.A.; Molan, P.C.; Harding, K.G. Antibacterial activity of honey against strains of Staphylococcus aureus from infected wounds. J. R. Soc. Med. 1999, 92, 283-285. [CrossRef] [PubMed]

135. Estevinho, L.; Pereira, A.P.; Moreira, L.; Dias, L.G.; Pereira, E. Antioxidant and antimicrobial effects of phenolic compounds extracts of Northeast Portugal honey. Food Chem. Toxicol. 2008, 46, 3774-3779. [CrossRef] [PubMed]

136. Roberts, A.E.L.; Brown, H.L.; Jenkins, R.E. On the Antibacterial Effects of Manuka Honey: Mechanistic Insights. Available online: https:/ / www.dovepress.com/on-the-antibacterial-effects-of-manuka-honeymechanistic-insights-peer-reviewed-fulltext-article-RRB (accessed on 19 March 2018).

137. Ettayebi, K.; El Yamani, J.; Rossi-Hassani, B. Synergistic effects of nisin and thymol on antimicrobial activities in Listeria monocytogenes and Bacillus subtilis. FEMS Microbiol. Lett. 2006, 183, 191-195. [CrossRef]

138. Donsì, F.; Ferrari, G. Essential oil nanoemulsions as antimicrobial agents in food. J. Biotechnol. 2016, 233, 106-120. [CrossRef] [PubMed]

139. Ghosh, A.; Ricke, S.C.; Almeida, G.; Gibson, K.E. Combined Application of Essential Oil Compounds and Bacteriophage to Inhibit Growth of Staphylococcus aureus In Vitro. Curr. Microbiol. 2016, 72, 426-435. [CrossRef] [PubMed]

140. Landry, E.F.; Zsigray, R.M. Effects of calcium on the lytic cycle of Bacillus subtilis phage 41c. J. Gen. Virol. 1980, 51, 125-135. [CrossRef] [PubMed]

141. Pham, M.; Mintz, E.A.; Nguyen, T.H. Deposition kinetics of bacteriophage MS2 to natural organic matter: Role of divalent cations. J. Colloid Interface Sci. 2009, 338, 1-9. [CrossRef] [PubMed]

142. Chhibber, S.; Kaur, T.; Kaur, S. Essential role of calcium in the infection process of broad-spectrum methicillin-resistant Staphylococcus aureus bacteriophage. J. Basic Microbiol. 2014, 54, 775-780. [CrossRef] [PubMed]

143. Bandara, N.; Jo, J.; Ryu, S.; Kim, K.-P. Bacteriophages BCP1-1 and BCP8-2 require divalent cations for efficient control of Bacillus cereus in fermented foods. Food Microbiol. 2012, 31, 9-16. [CrossRef] [PubMed]

144. Marrucho, I.M.; Branco, L.C.; Rebelo, L.P.N. Ionic liquids in pharmaceutical applications. Annu. Rev. Chem. Biomol. Eng. 2014, 5, 527-546. [CrossRef] [PubMed] 
145. San, K.; Long, J.; Michels, C.A.; Gadura, N. Antimicrobial copper alloy surfaces are effective against vegetative but not sporulated cells of gram-positive Bacillus subtilis. MicrobiologyOpen 2015, 4, 753-763. [CrossRef] [PubMed]

146. Kohler, L.J.; Quirk, A.V.; Welkos, S.L.; Cote, C.K. Incorporating germination-induction into decontamination strategies for bacterial spores. J. Appl. Microbiol. 2017. [CrossRef] [PubMed]

147. Nakonieczna, A.; Cooper, C.J.; Gryko, R. Bacteriophages and bacteriophage-derived endolysins as potential therapeutics to combat Gram-positive spore forming bacteria. J. Appl. Microbiol. 2015, 119, 620-631. [CrossRef] [PubMed]

148. Bishop, A.H. Germination and persistence of Bacillus anthracis and Bacillus thuringiensis in soil microcosms. J. Appl. Microbiol. 2014, 117, 1274-1282. [CrossRef] [PubMed]

149. Negus, D.; Taylor, P.W. A poly- $\gamma$-(D)-glutamic acid depolymerase that degrades the protective capsule of Bacillus anthracis. Mol. Microbiol. 2014, 91, 1136-1147. [CrossRef] [PubMed]

150. Yang, H.; Wang, D.-B.; Dong, Q.; Zhang, Z.; Cui, Z.; Deng, J.; Yu, J.; Zhang, X.-E.; Wei, H. Existence of separate domains in lysin PlyG for recognizing Bacillus anthracis spores and vegetative cells. Antimicrob. Agents Chemother. 2012, 56, 5031-5039. [CrossRef] [PubMed]

151. Buhr, T.L.; Young, A.A.; Barnette, H.K.; Minter, Z.A.; Kennihan, N.L.; Johnson, C.A.; Bohmke, M.D.; DePaola, M.; Cora-Laó, M.; Page, M.A. Test methods and response surface models for hot, humid air decontamination of materials contaminated with dirty spores of Bacillus anthracis $\Delta$ Sterne and Bacillus thuringiensis Al Hakam. J. Appl. Microbiol. 2015, 119, 1263-1277. [CrossRef] [PubMed]

152. Setlow, P. Germination of Spores of Bacillus Species: What We Know and Do Not Know. J. Bacteriol. 2014, 196, 1297-1305. [CrossRef] [PubMed]

153. Paredes-Sabja, D.; Torres, J.A.; Setlow, P.; Sarker, M.R. Clostridium perfringens spore germination: Characterization of germinants and their receptors. J. Bacteriol. 2008, 190, 1190-1201. [CrossRef] [PubMed]

154. Wheeldon, L.J.; Worthington, T.; Lambert, P.A. Histidine acts as a co-germinant with glycine and taurocholate for Clostridium difficile spores. J. Appl. Microbiol. 2011, 110, 987-994. [CrossRef] [PubMed]

155. Römling, U.; Balsalobre, C. Biofilm infections, their resilience to therapy and innovative treatment strategies. J. Intern. Med. 2012, 272, 541-561. [CrossRef] [PubMed]

156. Bjarnsholt, T. The role of bacterial biofilms in chronic infections. APMIS Suppl. 2013, 121, 1-51. [CrossRef] [PubMed]

157. Wolcott, R.; Costerton, J.W.; Raoult, D.; Cutler, S.J. The polymicrobial nature of biofilm infection. Clin. Microbiol. Infect. 2013, 19, 107-112. [CrossRef] [PubMed]

158. Høiby, N.; Bjarnsholt, T.; Givskov, M.; Molin, S.; Ciofu, O. Antibiotic resistance of bacterial biofilms. Int. J. Antimicrob. Agents 2010, 35, 322-332. [CrossRef] [PubMed]

159. Choi, O.; Yu, C.-P.; Esteban Fernández, G.; Hu, Z. Interactions of nanosilver with Escherichia coli cells in planktonic and biofilm cultures. Water Res. 2010, 44, 6095-6103. [CrossRef] [PubMed]

160. González, A.G.; Shirokova, L.S.; Pokrovsky, O.S.; Emnova, E.E.; Martínez, R.E.; Santana-Casiano, J.M.; González-Dávila, M.; Pokrovski, G.S. Adsorption of copper on Pseudomonas aureofaciens: Protective role of surface exopolysaccharides. J. Colloid Interface Sci. 2010, 350, 305-314. [CrossRef] [PubMed]

161. Barr, J.J.; Auro, R.; Furlan, M.; Whiteson, K.L.; Erb, M.L.; Pogliano, J.; Stotland, A.; Wolkowicz, R.; Cutting, A.S.; Doran, K.S.; et al. Bacteriophage adhering to mucus provide a non-host-derived immunity. Proc. Natl. Acad. Sci. USA 2013, 110, 10771-10776. [CrossRef] [PubMed]

162. Tseng, B.S.; Zhang, W.; Harrison, J.J.; Quach, T.P.; Song, J.L.; Penterman, J.; Singh, P.K.; Chopp, D.L.; Packman, A.I.; Parsek, M.R. The extracellular matrix protects Pseudomonas aeruginosa biofilms by limiting the penetration of tobramycin. Environ. Microbiol. 2013, 15, 2865-2878. [CrossRef] [PubMed]

163. Yan, J.; Mao, J.; Mao, J.; Xie, J. Bacteriophage polysaccharide depolymerases and biomedical applications. BioDrugs 2014, 28, 265-274. [CrossRef] [PubMed]

164. Shang, A.; Liu, Y.; Wang, J.; Mo, Z.; Li, G.; Mou, H. Complete nucleotide sequence of Klebsiella phage P13 and prediction of an EPS depolymerase gene. Virus Genes 2015, 50, 118-128. [CrossRef] [PubMed]

165. Latka, A.; Maciejewska, B.; Majkowska-Skrobek, G.; Briers, Y.; Drulis-Kawa, Z. Bacteriophage-encoded virion-associated enzymes to overcome the carbohydrate barriers during the infection process. Appl. Microbiol. Biotechnol. 2017, 101, 3103-3119. [CrossRef] [PubMed]

166. Cataldi, M.; Sblendorio, V.; Leo, A.; Piazza, O. Biofilm-dependent airway infections: A role for ambroxol? Pulm. Pharmacol. Ther. 2014, 28, 98-108. [CrossRef] [PubMed] 
167. Zhao, T.; Liu, Y. N-acetylcysteine inhibit biofilms produced by Pseudomonas aeruginosa. BMC Microbiol. 2010, 10, 140. [CrossRef] [PubMed]

168. Hernandez-Morales, A.C.; Lessor, L.L.; Wood, T.L.; Migl, D.; Mijalis, E.M.; Russell, W.K.; Young, R.F.; Gill, J.J. Genomic and Biochemical Characterization of Acinetobacter Podophage Petty Reveals a Novel Lysis Mechanism and Tail-Associated Depolymerase Activity. J. Virol. 2018, JVI.01064-17. [CrossRef] [PubMed]

169. Lai, M.-J.; Chang, K.-C.; Huang, S.-W.; Luo, C.-H.; Chiou, P.-Y.; Wu, C.-C.; Lin, N.-T. The Tail Associated Protein of Acinetobacter baumannii Phage $\Phi A B 6$ is the Host Specificity Determinant Possessing Exopolysaccharide Depolymerase Activity. PLoS ONE 2016, 11, e0153361. [CrossRef] [PubMed]

170. Guo, Z.; Huang, J.; Yan, G.; Lei, L.; Wang, S.; Yu, L.; Zhou, L.; Gao, A.; Feng, X.; Han, W.; et al. Identification and Characterization of Dpo42, a Novel Depolymerase Derived from the Escherichia coli Phage vB_EcoM_ECOO78. Front. Microbiol. 2017, 8, 1460. [CrossRef] [PubMed]

171. Lin, H.; Paff, M.L.; Molineux, I.J.; Bull, J.J. Therapeutic Application of Phage Capsule Depolymerases against K1, K5, and K30 Capsulated E. coli in Mice. Front. Microbiol. 2017, 8. [CrossRef] [PubMed]

172. Pan, Y.-J.; Lin, T.-L.; Chen, C.-C.; Tsai, Y.-T.; Cheng, Y.-H.; Chen, Y.-Y.; Hsieh, P.-F.; Lin, Y.-T.; Wang, J.-T. Klebsiella Phage $\Phi$ K64-1 Encodes Multiple Depolymerases for Multiple Host Capsular Types. J. Virol. 2017, 91, e02457-16. [CrossRef] [PubMed]

173. Hsieh, P.-F.; Lin, H.-H.; Lin, T.-L.; Chen, Y.-Y.; Wang, J.-T. Two T7-like Bacteriophages, K5-2 and K5-4, Each Encodes Two Capsule Depolymerases: Isolation and Functional Characterization. Sci. Rep. 2017, 7, 4624. [CrossRef] [PubMed]

174. Pyra, A.; Brzozowska, E.; Pawlik, K.; Gamian, A.; Dauter, M.; Dauter, Z. Tail tubular protein A: A dual-function tail protein of Klebsiella pneumoniae bacteriophage KP32. Sci. Rep. 2017, 7, 2223. [CrossRef] [PubMed]

175. Born, Y.; Fieseler, L.; Klumpp, J.; Eugster, M.R.; Zurfluh, K.; Duffy, B.; Loessner, M.J. The tail-associated depolymerase of Erwinia amylovora phage L1 mediates host cell adsorption and enzymatic capsule removal, which can enhance infection by other phage. Environ. Microbiol. 2014, 16, 2168-2180. [CrossRef] [PubMed]

176. Kumari, S.; Harjai, K.; Chhibber, S. Bacteriophage versus antimicrobial agents for the treatment of murine burn wound infection caused by Klebsiella pneumoniae B5055. J. Med. Microbiol. 2011, 60, 205-210. [CrossRef] [PubMed]

177. Ma, Y.; Pacan, J.C.; Wang, Q.; Sabour, P.M.; Huang, X.; Xu, Y. Enhanced alginate microspheres as means of oral delivery of bacteriophage for reducing Staphylococcus aureus intestinal carriage. Food Hydrocoll. 2012, 2, 434-440. [CrossRef]

178. Soto, M.J.; Retamales, J.; Palza, H.; Bastías, R. Encapsulation of specific Salmonella Enteritidis phage f3 $\alpha \mathrm{SE}$ on alginate-spheres as a method for protection and dosification. Electron. J. Biotechnol. 2018, 31, 57-60. [CrossRef]

179. Vinner, G.K.; Vladisavljević, G.T.; Clokie, M.R.J.; Malik, D.J. Microencapsulation of Clostridium difficile specific bacteriophages using microfluidic glass capillary devices for colon delivery using $\mathrm{pH}$ triggered release. PLoS ONE 2017, 12, e0186239. [CrossRef] [PubMed]

180. Hathaway, H.; Ajuebor, J.; Stephens, L.; Coffey, A.; Potter, U.; Sutton, J.M.; Jenkins, A.T.A. Thermally triggered release of the bacteriophage endolysin CHAPK and the bacteriocin lysostaphin for the control of methicillin resistant Staphylococcus aureus (MRSA). J. Control. Release 2017, 245, 108-115. [CrossRef] [PubMed]

181. Ryan, E.M.; Gorman, S.P.; Donnelly, R.F.; Gilmore, B.F. Recent advances in bacteriophage therapy: How delivery routes, formulation, concentration and timing influence the success of phage therapy. J. Pharm. Pharmacol. 2011, 63, 1253-1264. [CrossRef] [PubMed]

182. Hathaway, H.; Milo, S.; Sutton, J.M.; Jenkins, T.A. Recent advances in therapeutic delivery systems of bacteriophage and bacteriophage-encoded endolysins. Ther. Deliv. 2017, 8, 543-556. [CrossRef] [PubMed]

183. Bustamante, N.; Rico-Lastres, P.; García, E.; García, P.; Menéndez, M. Thermal Stability of Cpl-7 Endolysin from the Streptococcus pneumoniae Bacteriophage Cp-7; Cell Wall-Targeting of Its CW_7 Motifs. PLoS ONE 2012, 7, e46654. [CrossRef] [PubMed]

184. Son, B.; Yun, J.; Lim, J.-A.; Shin, H.; Heu, S.; Ryu, S. Characterization of LysB4, an endolysin from the Bacillus cereus-infecting bacteriophage B4. BMC Microbiol. 2012, 12, 33. [CrossRef] [PubMed]

185. Walmagh, M.; Boczkowska, B.; Grymonprez, B.; Briers, Y.; Drulis-Kawa, Z.; Lavigne, R. Characterization of five novel endolysins from Gram-negative infecting bacteriophages. Appl. Microbiol. Biotechnol. 2013, 97, 4369-4375. [CrossRef] [PubMed] 
186. Malik, D.J.; Sokolov, I.J.; Vinner, G.K.; Mancuso, F.; Cinquerrui, S.; Vladisavljevic, G.T.; Clokie, M.R.J.; Garton, N.J.; Stapley, A.G.F.; Kirpichnikova, A. Formulation, stabilisation and encapsulation of bacteriophage for phage therapy. Adv. Colloid Interface Sci. 2017, 249, 100-133. [CrossRef] [PubMed]

187. Pati, R.; Sahu, R.; Panda, J.; Sonawane, A. Encapsulation of zinc-rifampicin complex into transferrin-conjugated silver quantum-dots improves its antimycobacterial activity and stability and facilitates drug delivery into macrophages. Sci. Rep. 2016, 6, 24184. [CrossRef] [PubMed]

188. Leung, S.S.Y.; Parumasivam, T.; Gao, F.G.; Carrigy, N.B.; Vehring, R.; Finlay, W.H.; Morales, S.; Britton, W.J.; Kutter, E.; Chan, H.-K. Production of Inhalation Phage Powders Using Spray Freeze Drying and Spray Drying Techniques for Treatment of Respiratory Infections. Pharm. Res. 2016, 33, 1486-1496. [CrossRef] [PubMed]

189. Leung, S.S.Y.; Parumasivam, T.; Gao, F.G.; Carter, E.A.; Carrigy, N.B.; Vehring, R.; Finlay, W.H.; Morales, S.; Britton, W.J.; Kutter, E.; et al. Effects of storage conditions on the stability of spray dried, inhalable bacteriophage powders. Int. J. Pharm. 2017, 521, 141-149. [CrossRef] [PubMed]

190. Niwa, K.; Takaya, T.; Morimoto, T.; Takada, K. Preparation and evaluation of a time-controlled release capsule made of ethylcellulose for colon delivery of drugs. J. Drug Target. 1995, 3, 83-89. [CrossRef] [PubMed]

191. Amabile, C.M.; Bowman, B.J. Overview of Oral Modified-Release Opioid Products for the Management of Chronic Pain. Ann. Pharmacother. 2006, 40, 1327-1335. [CrossRef] [PubMed]

192. Shargel, L.; Andrew, B.; Wu-Pong, S. Applied Biopharmaceutics \& Pharmacokinetics; McGraw-Hill Medical Publishing Division: New York, NY, USA, 2015; pp. 119-120.

193. Fukuda, K.; Ishida, W.; Uchiyama, J.; Rashel, M.; Kato, S.; Morita, T.; Muraoka, A.; Sumi, T.; Matsuzaki, S.; Daibata, M.; et al. Pseudomonas aeruginosa Keratitis in Mice: Effects of Topical Bacteriophage KPP12 Administration. PLoS ONE 2012, 7, e47742. [CrossRef] [PubMed]

194. Sarker, S.A.; McCallin, S.; Barretto, C.; Berger, B.; Pittet, A.-C.; Sultana, S.; Krause, L.; Huq, S.; Bibiloni, R.; Bruttin, A.; et al. Oral T4-like phage cocktail application to healthy adult volunteers from Bangladesh. Virology 2012, 434, 222-232. [CrossRef] [PubMed]

195. McCallin, S.; Alam, S.S.; Barretto, C.; Sultana, S.; Berger, B.; Huq, S.; Krause, L.; Bibiloni, R.; Schmitt, B.; Reuteler, G.; et al. Safety analysis of a Russian phage cocktail: From metagenomic analysis to oral application in healthy human subjects. Virology 2013, 443, 187-196. [CrossRef] [PubMed]

196. Sarker, S.A.; Sultana, S.; Reuteler, G.; Moine, D.; Descombes, P.; Charton, F.; Bourdin, G.; McCallin, S.; Ngom-Bru, C.; Neville, T.; et al. Oral Phage Therapy of Acute Bacterial Diarrhea With Two Coliphage Preparations: A Randomized Trial in Children From Bangladesh. EBioMedicine 2016, 4, 124-137. [CrossRef] [PubMed]

197. Xu, S.; Nie, Z.; Seo, M.; Lewis, P.; Kumacheva, E.; Stone, H.A.; Garstecki, P.; Weibel, D.B.; Gitlin, I.; Whitesides, G.M. Generation of Monodisperse Particles by Using Microfluidics: Control over Size, Shape, and Composition. Angew. Chem. 2005, 44, 724-728. [CrossRef] [PubMed]

198. Yousefi, M.; Inthavong, K.; Tu, J. Effect of Pressurized Metered Dose Inhaler Spray Characteristics and Particle Size Distribution on Drug Delivery Efficiency. J. Aerosol Med. Pulm. Drug Deliv. 2017, 30, 359-372. [CrossRef] [PubMed]

199. Griesang, F.; Decaro, R.A.; dos Santos, C.A.M.; Santos, E.S.; de Lima Roque, N.H.; da Costa Ferreira, M. How Much Do Adjuvant and Nozzles Models Reduce the Spraying Drift? Drift in Agricultural Spraying. Am. J. Plant Sci. 2017, 8, 2785. [CrossRef]

200. Dufour, N.; Delattre, R.; Ricard, J.-D.; Debarbieux, L. The Lysis of Pathogenic Escherichia coli by Bacteriophages Releases Less Endotoxin Than by $\beta$-Lactams. Clin. Infect. Dis. 2017, 64, 1582-1588. [CrossRef] [PubMed]

201. Wang, Y.; Mi, Z.; Niu, W.; An, X.; Yuan, X.; Liu, H.; Li, P.; Liu, Y.; Feng, Y.; Huang, Y.; et al. Intranasal treatment with bacteriophage rescues mice from Acinetobacter baumannii-mediated pneumonia. Future Microbiol. 2016, 11, 631-641. [CrossRef] [PubMed]

202. Duplessis, C.; Biswas, B.; Hanisch, B.; Perkins, M.; Henry, M.; Quinones, J.; Wolfe, D.; Estrella, L.; Hamilton, T. Refractory Pseudomonas Bacteremia in a 2-Year-Old Sterilized by Bacteriophage Therapy. J. Pediatr. Infect. Dis. Soc. 2017. [CrossRef] [PubMed]

203. Verheust, C.; Goossens, M.; Pauwels, K.; Breyer, D. Biosafety aspects of modified vaccinia virus Ankara (MVA)-based vectors used for gene therapy or vaccination. Vaccine 2012, 30, 2623-2632. [CrossRef] [PubMed] 
204. Cho, S.-Y.; Park, S.-J.; Kwon, M.-J.; Jeong, T.-S.; Bok, S.-H.; Choi, W.-Y.; Jeong, W.-I.; Ryu, S.-Y.; Do, S.-H.; Lee, C.-S.; et al. Quercetin suppresses proinflammatory cytokines production through MAP kinases and NF-kappaB pathway in lipopolysaccharide-stimulated macrophage. Mol. Cell. Biochem. 2003, 243, 153-160. [CrossRef] [PubMed]

205. Vallespi, M.G.; Alvarez-Obregón, J.C.; Rodriguez-Alonso, I.; Montero, T.; Garay, H.; Reyes, O.; Araña, M.J. A Limulus anti-LPS factor-derived peptide modulates cytokine gene expression and promotes resolution of bacterial acute infection in mice. Int. Immunopharmacol. 2003, 3, 247-256. [CrossRef]

206. David, S.A.; Silverstein, R.; Amura, C.R.; Kielian, T.; Morrison, D.C. Lipopolyamines: Novel Antiendotoxin Compounds That Reduce Mortality in Experimental Sepsis Caused by Gram-Negative Bacteria. Antimicrob. Agents Chemother. 1999, 43, 912-919. [PubMed]

207. Hu, Y.; Mao, A.; Yu, Z.; He, K. Anti-endotoxin and anti-inflammatory effects of Chinese herbal medicinal alkaloid ingredients in vivo. Microb. Pathog. 2016, 99, 51-55. [CrossRef] [PubMed]

208. Kim, K.-P.; Cha, J.-D.; Jang, E.-H.; Klumpp, J.; Hagens, S.; Hardt, W.-D.; Lee, K.-Y.; Loessner, M.J. PEGylation of bacteriophages increases blood circulation time and reduces T-helper type 1 immune response. Microb. Biotechnol. 2008, 1, 247-257. [CrossRef] [PubMed]

209. Goodridge, L.D. Designing Phage Therapeutics. Available online: http://www.eurekaselect.com/71081/ article (accessed on 19 March 2018).

210. Resch, G.; Moreillon, P.; Fischetti, V.A. PEGylating a bacteriophage endolysin inhibits its bactericidal activity. $A M B$ Express 2011, 1, 29. [CrossRef] [PubMed]

211. Golshahi, L.; Lynch, K.H.; Dennis, J.J.; Finlay, W.H. In vitro lung delivery of bacteriophages KS4-M and $\Phi \mathrm{KZ}$ using dry powder inhalers for treatment of Burkholderia cepacia complex and Pseudomonas aeruginosa infections in cystic fibrosis. J. Appl. Microbiol. 2011, 110, 106-117. [CrossRef] [PubMed]

212. Fish, R.; Kutter, E.; Wheat, G.; Blasdel, B.; Kutateladze, M.; Kuhl, S. Bacteriophage treatment of intransigent diabetic toe ulcers: A case series. J. Wound Care 2016, 25 (Suppl. 7), S27-S33. [CrossRef] [PubMed]

213. Uimajuridze, A.; Jvania, G.; Chanishvili, N.; Goderdzishvili, M.; Sybesma, W.; Managadze, L.; Chkhotua, A.; Kessler, T. 265 Phage therapy for the treatment for urinary tract infection: Results of in-vitro screenings and in-vivo application using commercially available bacteriophage cocktails. Eur. Urol. Suppl. 2016, 15, e265. [CrossRef]

(C) 2018 by the authors. Licensee MDPI, Basel, Switzerland. This article is an open access article distributed under the terms and conditions of the Creative Commons Attribution (CC BY) license (http://creativecommons.org/licenses/by/4.0/). 